\title{
MARINe ARChAEOLOGY AsSESSMENT of The South Terminal ProJect ORANGe AND JefFerson CoUnTIES, TEXAS
}

Prepared for:

Horizon Environmental Services, Inc.

1507 South Interstate 35

Austin, Texas 78741

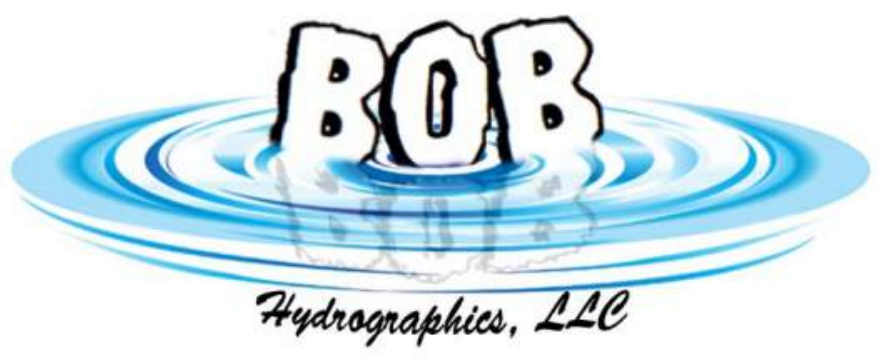

Prepared by:

BOB Hydrographics, LLC

1315 Fall Creek Loop

Cedar Park, Texas 78613

Principal Investigator:

Robert Gearhart

April 2020 


\section{MARINE ARCHAEOLOGY ASSESSMENT \\ OF THE SOUTH TERMINAL PROJECT \\ ORANGE AND JEFFERSON COUNTIES, TEXAS}

Texas Antiquities Permit No. 8926

Prepared for:

Horizon Environmental Services, Inc.

1507 South Interstate 35

Austin, Texas 78741

Prepared by:

BOB Hydrographics, LLC

1315 Fall Creek Loop

Cedar Park, Texas 78613

Principal Investigator:

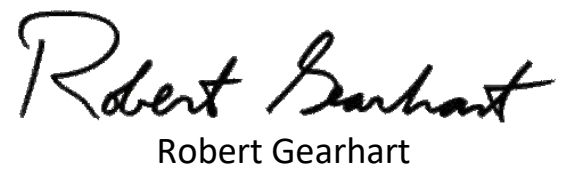

April 2020

ii | P a g e 


\section{Table of Contents}

Page

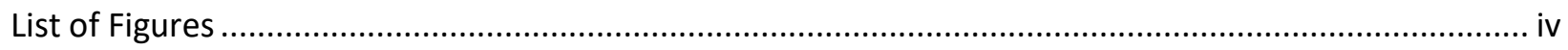

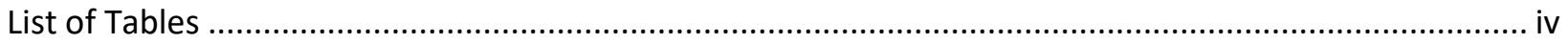

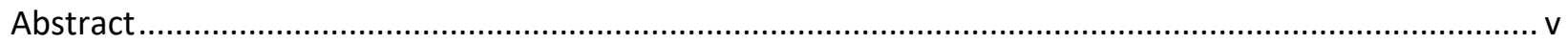

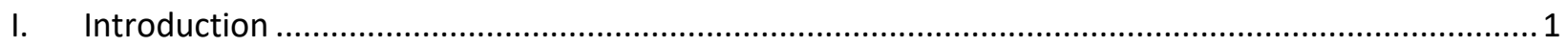

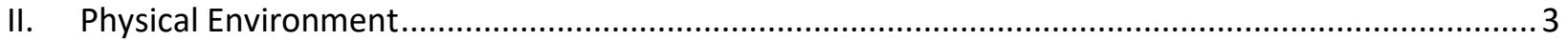

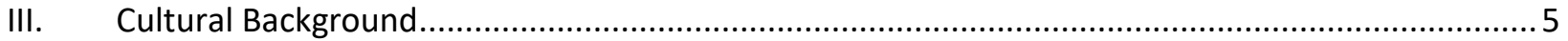

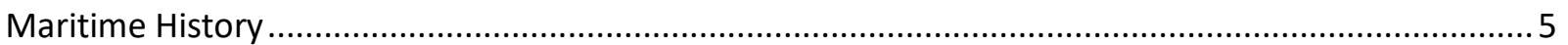

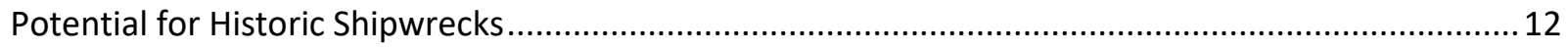

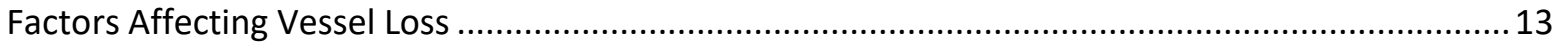

Factors Affecting Vessel Preservation......................................................................... 14

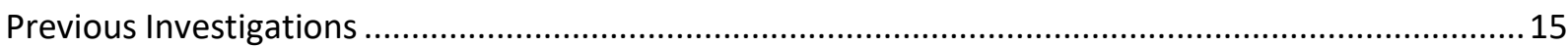

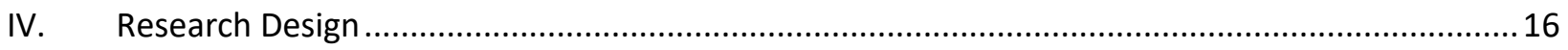

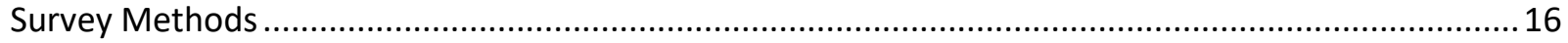

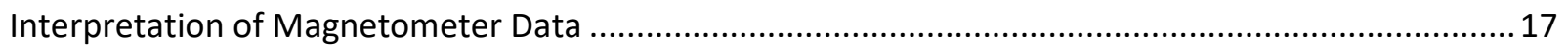

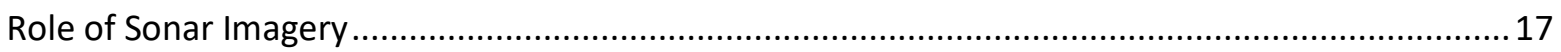

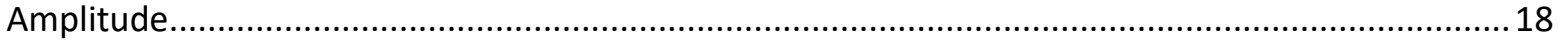

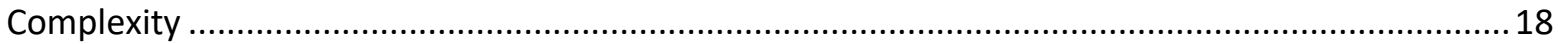

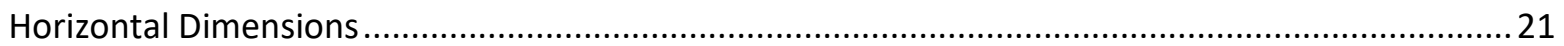

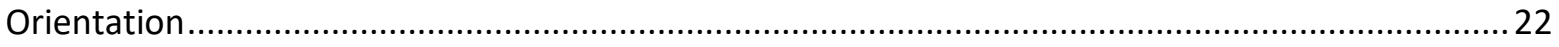

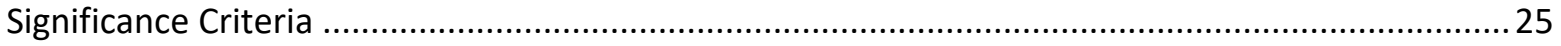

Probing Unidentified Anomalies ................................................................................ 25

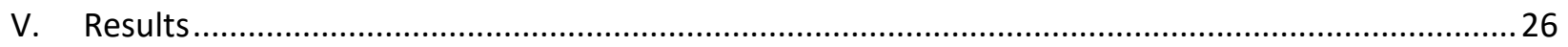

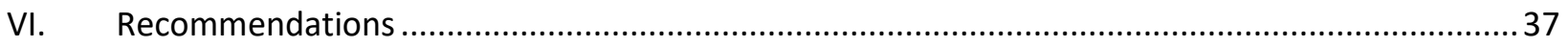

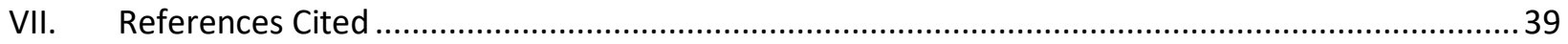

Appendix A: Geophysical Survey Results (Not for Public Disclosure) ............................................ A-1

Appendix B: Summary of Significant Findings (Not for Public Disclosure) .........................................

Appendix C: Probing Results and Positions (Not for Public Disclosure) ............................................

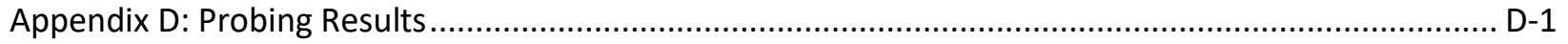

Appendix E: Texas Antiquities Permit 8926 and Agency Correspondence............................................

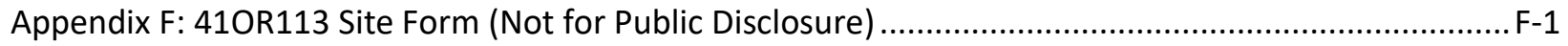

iii | P a g e 


\section{List of Figures}

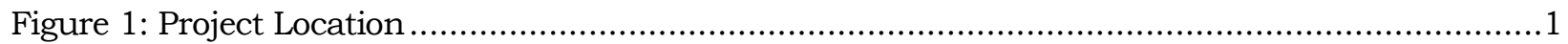

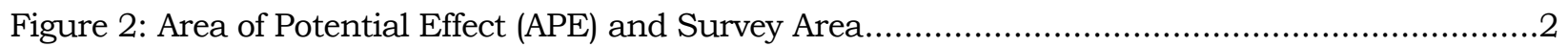

Figure 3: Survey Area in 1911 (U.S. Army Corps of Engineers 1911) ..........................................

Figure 4: Survey Area in 1926 (United States Coast and Geodetic Survey 1926) ...........................4

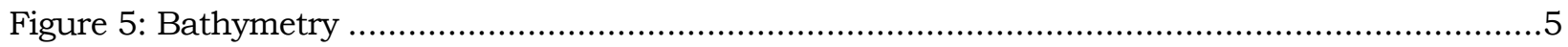

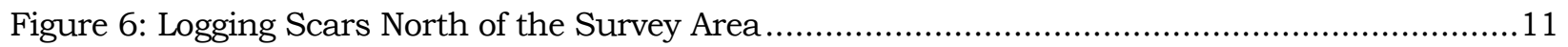

Figure 7: Example of a Verified Shipwreck Anomaly, Site 41CL92 …....................................20

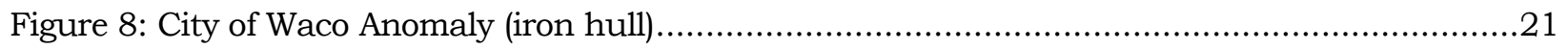

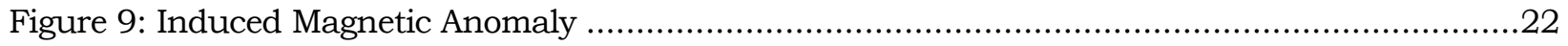

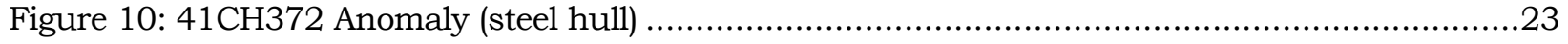

Figure 11: Mag-13 Wreck Anomaly (wooden hull) ............................................................24

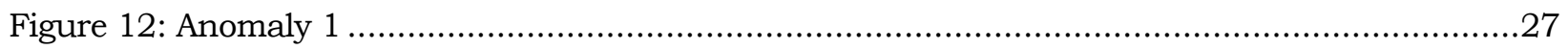

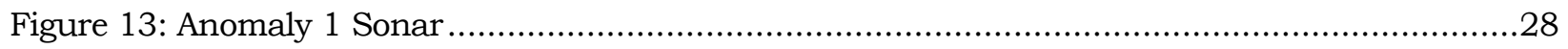

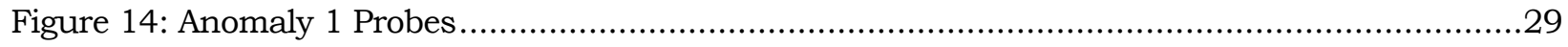

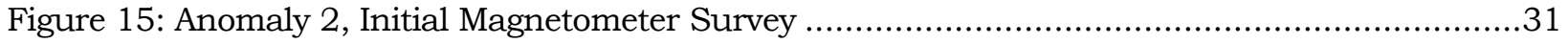

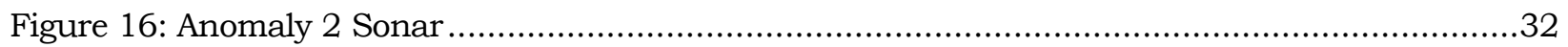

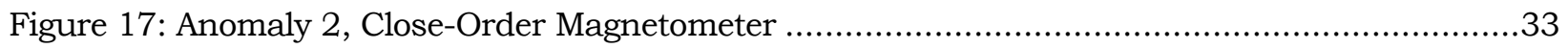

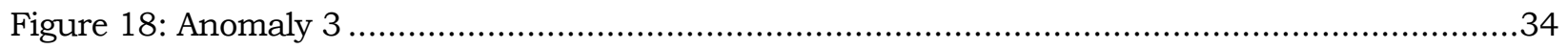

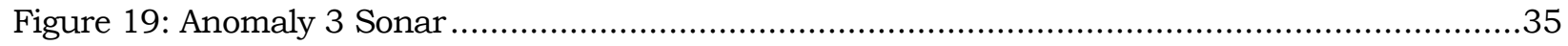

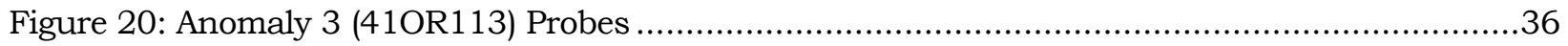

\section{List of Tables}

Table 1: Wrecks Reported Within Three River Miles of Survey Area .......................................13

Table 2: Previous Marine Investigations Within 3 River Miles of the Survey Area ..........................15 


\section{Abstract}

BOB Hydrographics, LLC (BOB) conducted a marine archaeological assessment in support of the Orange County South Terminal Project. The South Terminal is proposed on an oxbow channel of the Neches River, downstream from Beaumont, to accommodate loading and unloading of ships and barges and an adjacent tank storage facility. Plans for marine portions of the property include construction of two ship docks and one new barge dock. Dredging will remove sediments down to an elevation of -42 feet ( $\mathrm{ft}$ ) Mean Lower Low Water (MLLW) to create ship berths and a turning basin. Planned future expansion would increase the depth of the berths and turning basin to $-48 \mathrm{ft}$ MLLW. A barge dock will be dredged along the edge of the Neches River Channel to an elevation of $-17 \mathrm{ft}$ MLLW. Pilings will be driven to support dock and gangway platforms and to create mooring and breasting dolphins and barge monopiles. A portion of the oxbow, west of the ship docks will be filled to create upland as part of a proposed storage tank facility.

Horizon Environmental Services, Inc. contracted with BOB, on behalf of the project sponsor, Port of Beaumont Navigation District, to assess the potential for submerged archaeological sites within the proposed South Terminal. Submerged archaeological sites, in this context, might be historic sites, such as sunken or abandoned watercraft, which may be eligible for the National Register of Historic Places or as State Antiquities Landmarks. The South Terminal will be constructed on publicly owned land; therefore, Texas Antiquities Permit 8926 was obtained prior to beginning fieldwork. A review of the cultural background determined that 3 prior marine archaeological investigations have been conducted within 3 miles of this project. At least 7 wrecks have been reported within 3 miles of the survey area.

Field investigations included marine geophysical survey and probing of 2 anomalies. Geophysical survey was completed by BOB from June 10-13, 2019. A total of 78 acres was surveyed. The submerged Area of Potential Effect totals 54.7 acres, including: 34.3 acres for dredging ship and barge berths, 10.3 acres for ship docks and storage tanks, and 10.1 acres of survey buffer, mandated by the Texas Historical Commission, along the eastern margin of the dredging footprint. The Principal Investigator was solely responsible for archaeological data analysis and report preparation.

Preliminary analysis of geophysical survey data resulted in recommendations of archaeological avoidance for 3 potential historic sites, designated as Anomalies 1, 2 and 3. Additional investigation was conducted from August 26-29, 2019 and January 19-21, 2020. Probing disproved the significance of Anomaly 1. Closeorder magnetometer survey disproved the significance of Anomaly 2. Probing determined that Anomaly 3 is associated with a buried, wooden-hulled watercraft, Site 41OR113, measuring 32 feet wide and at least $82 \mathrm{ft}$ long. Site $410 R 113$ is potentially eligible as a State Antiquities Landmark and for listing in the National Register of Historic Places. All disturbance of the river bottom, related to construction of the South Terminal, must be avoided within state-mandated target avoidance buffers extending 50 meters beyond the margins Site 410R113. If the wreck cannot be successfully avoided, then further investigation would be required to determine whether the site is historically significant and eligible for the National Register of Historic Places. All portions of the survey area, outside of the $410 R 113$ avoidance zone, are recommended for archaeological clearance.

This study was completed in compliance with Section 106 of the National Historic Preservation Act of 1966, as amended (Public Law 89-665; 16 U.S.C. 470), requiring that the lead agency consider the effects of projects upon historic resources, if those projects receive either permits or funding from the federal 
government. This study complies with the Antiquities Code of Texas (Texas Natural Resource Code, Title 9, Chapter 191), which provides for the protection of cultural resources on state lands. Title 13, Part 2, Chapters 26 and 28 of The Texas Administrative Code mandates the minimum reporting and survey requirements, respectively, for marine archaeological studies conducted under Texas Antiquities Permits. Archaeological project records are curated at the Center for Archeological Studies at Texas State University in San Marcos. No artifacts were collected during these investigations. 


\section{Introduction}

BOB Hydrographics, LLC (BOB) conducted a marine archaeological assessment in support of the Orange County South Terminal Project. The South Terminal is proposed on an oxbow channel of the Neches River, downstream from Beaumont (Figure 1). The South Terminal will accommodate loading and unloading of ships and barges adjacent a proposed tank storage facility. Plans for marine portions of the property (Figure 2) include construction of two ship docks for Suezmax vessels and one new barge dock. Dredging will remove sediments down to an elevation of -42 feet ( $\mathrm{ft}$ ) Mean Lower Low Water (MLLW) to create ship berths and a turning basin. Future expansion eventually will increase the depth of the berths and turning basin to $-48 \mathrm{ft}$ MLLW. A barge dock will be dredged along the edge of the Neches River Channel to an elevation of $-17 \mathrm{ft}$ MLLW. Pilings will be driven to support dock and gangway platforms and to create mooring and breasting dolphins and barge monopiles. A portion of the oxbow, west of the ship docks will be filled. A product storage tank will be constructed on the upland area created by filling this portion of the oxbow.

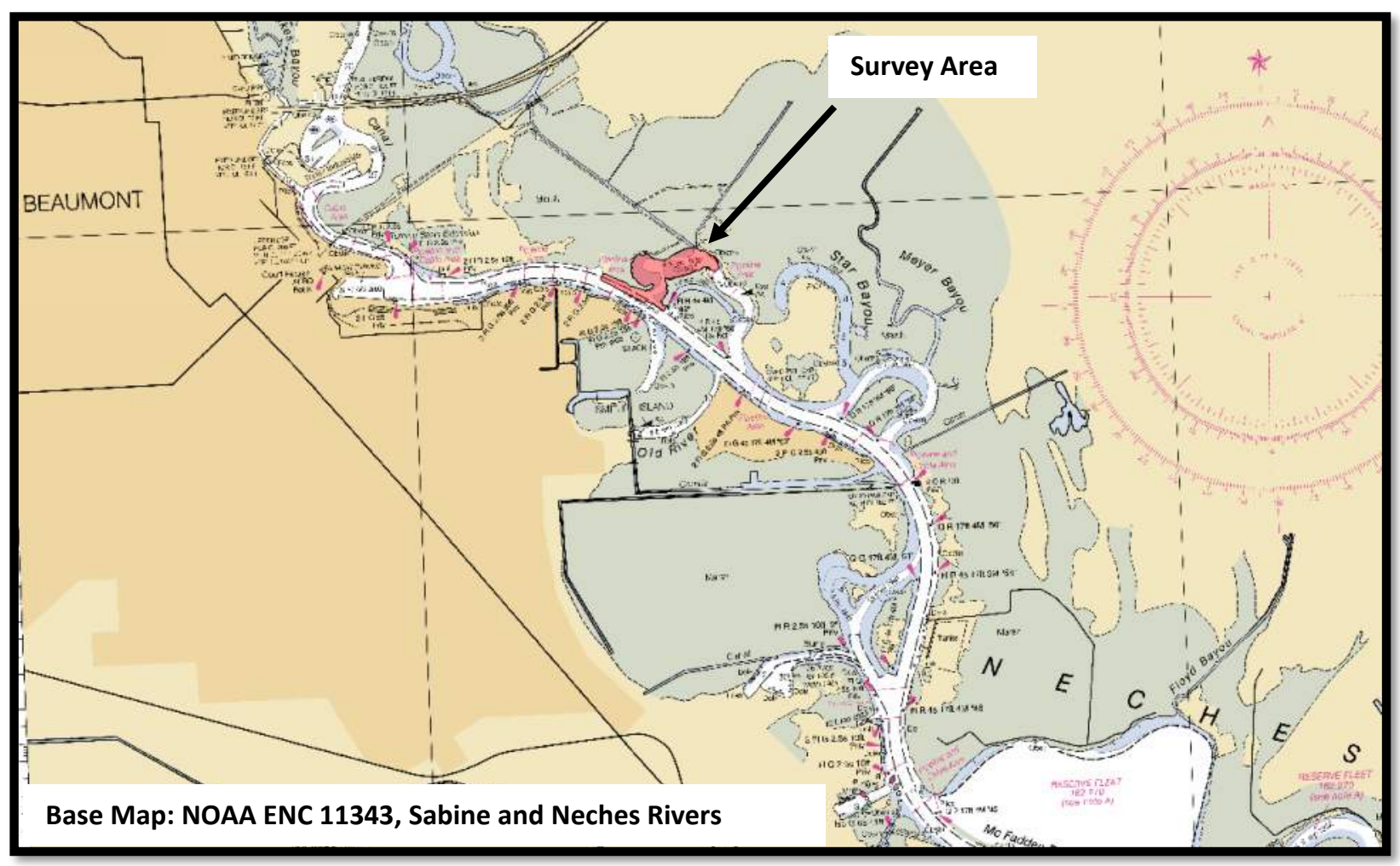

Figure 1: Project Location

Horizon Environmental Services, Inc. contracted with $\mathrm{BOB}$, on behalf of the project sponsor, Port of Beaumont Navigation District, to assess the potential for submerged archaeological sites within the proposed South Terminal. Submerged archaeological sites, in this context, might be historic sites, such as sunken or abandoned watercraft. Submerged historic remains may be eligible for nomination to the National Register of Historic Places or as State Antiquities Landmarks. A review of the cultural background 
determined that 3 prior marine archaeological investigations have been conducted within 3 miles of this project. At least 7 wrecks have been reported within 3 miles of the survey area.

The South Terminal will be constructed on publicly owned land; therefore, Texas Antiquities Permit 8926 was obtained prior to beginning fieldwork. Permit 8926 was amended on August 22, 2019 to include probing of two anomalies and close-order magnetometer survey of a third anomaly. Terrestrial portions of the South Terminal were assessed by Horizon Environmental Services, Inc. in a separate report under another antiquities permit.

The initial geophysical survey was completed by BOB from June 10-13, 2019. Probing and close-order survey was conducted from August 26-29, 2019. Additional probing was conducted on one anomaly from January 19-21, 2020 to rule out a deeply buried wreck, due to the presence of a thick, soft sediment overburden, interpreted as recent material. The geophysical and probing field crews included Robert Gearhart (Principal Investigator) and Ed Baxter, RPA. Michael Baxter assisted with probing efforts on both occasions. The Principal Investigator was solely responsible for archaeological data analysis and report preparation.

The submerged Area of Potential Effect (APE) totals 54.7 acres (Figure 2), including: 34.3 acres proposed for dredging ship and barge berths, 10.3 acres proposed for ship docks and storage tanks, and 10.1 acres of survey buffer along the eastern margin of the proposed dredging footprint. The Texas Historical Commission (THC) mandates a survey buffer extending 50 meters $(\mathrm{m})$ [164 ft] beyond the anticipated top of the slope for inshore marine projects. The survey was extended several hundred feet further east from the APE to ensure that sufficient coverage was obtained prior to leaving the field. The survey area totaled 78 acres.

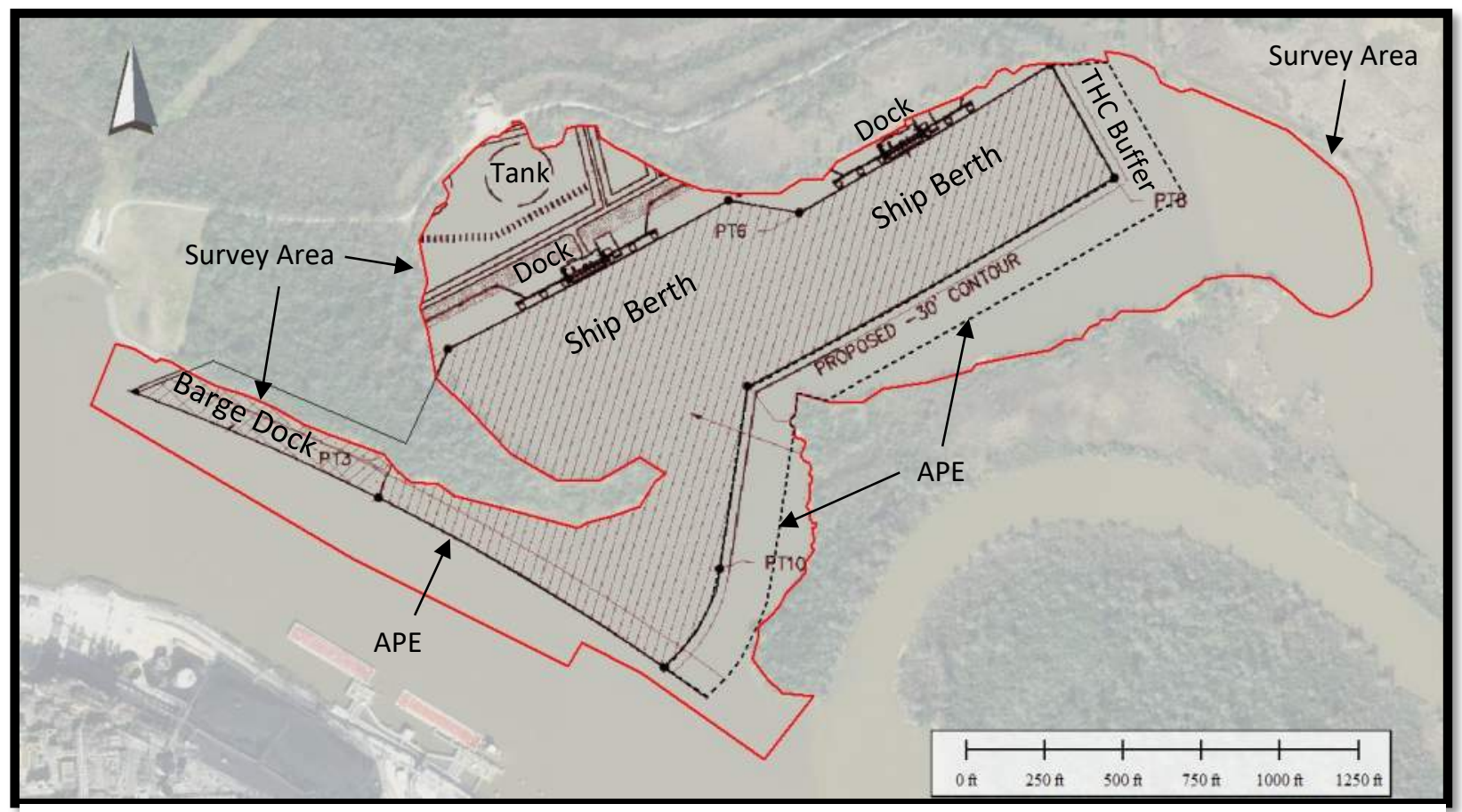

Figure 2: Area of Potential Effect (APE) and Survey Area Base Photo: 2015 DOQQ, top15-nc-cir-50cm-3094642-20150209.jp2 
Analysis of geophysical survey data from this investigation resulted in an initial recommendation of archaeological avoidance for 3 potential historic sites, designated as Anomalies 1, 2 and 3 . The significance of anomalies 1 and 2 was later disproved by probing and close-order magnetometer survey, respectively, so avoidance is no longer required for those two anomalies. A buried, wooden-hulled vessel, Site 41OR113, was discovered by probing of Anomaly 3. Disturbance of the river bottom must be avoided within 50 meters of this wreck. If Site $410 R 113$ cannot be successfully avoided, then further investigation would be required to determine whether the site is historically significant and potentially eligible for the National Register of Historic Places. All portions of the survey area, outside of the 410 R113 avoidance zone, are recommended for archaeological clearance.

This study was completed in compliance with Section 106 of the National Historic Preservation Act of 1966, as amended (Public Law 89-665; 16 U.S.C. 470), requiring that the lead agency consider the effects of projects upon historic resources, if those projects receive either permits or funding from the federal government. This study complies with the Antiquities Code of Texas (Texas Natural Resource Code, Title 9, Chapter 191), which provides for the protection of cultural resources on state lands. Title 13, Part 2, Chapters 26 and 28 of The Texas Administrative Code mandates the minimum reporting and survey requirements, respectively, for marine archaeological studies conducted under Texas Antiquities Permits. Archaeological project records are curated at the Center for Archeological Studies at Texas State University in San Marcos. No artifacts were collected during these investigations.

This report is organized into six sections that provide context for interpreting the survey results and includes maps of magnetic contours and side-scan sonar imagery. Section II relies upon a combination of published literature and data collected by this survey to summarize the physical environment. Section III summarizes the relevant cultural background within a 3-mile radius of the survey areas, including relevant maritime history, previous archaeological investigations, and the potential for intact historic sites. Section IV summarizes methods for conducting the geophysical survey, anomaly probing, data processing, and analysis. Section $\mathrm{V}$ presents an archaeological assessment of the geophysical and probing data. Archaeological recommendations are summarized in Section VI. Bibliographic references cited in the text are included as Section VII. Geophysical data maps are placed in non-public appendices to protect the locations of potential archaeological sites. Geophysical survey results are illustrated in Appendix A. Survey results and recommendations are tabulated in Appendix B. Probing results are tabulated in appendices $C$ and D. Texas Antiquities Permit 8926 and relevant agency correspondences are included as Appendix E.

\section{Physical Environment}

The proposed South Terminal is located in an oxbow channel of the Neches River about 2 miles downstream from Beaumont. The survey area straddles the line between Jefferson and Orange Counties. Orange County was carved from a larger Jefferson County in 1852 (Mason 2019). The river presumably flowed through this oxbow when the county line was established in 1852. An early chart hints that the river might have followed the oxbow channel in 1863, but the accuracy of the chart is insufficient to allow any strong conclusion (Von Rosenberg 1863). The Neches River began flowing along its present course, past the survey area, between 1911 and 1926 (compare figures 3 and 4). Figure 3 demonstrates that the 


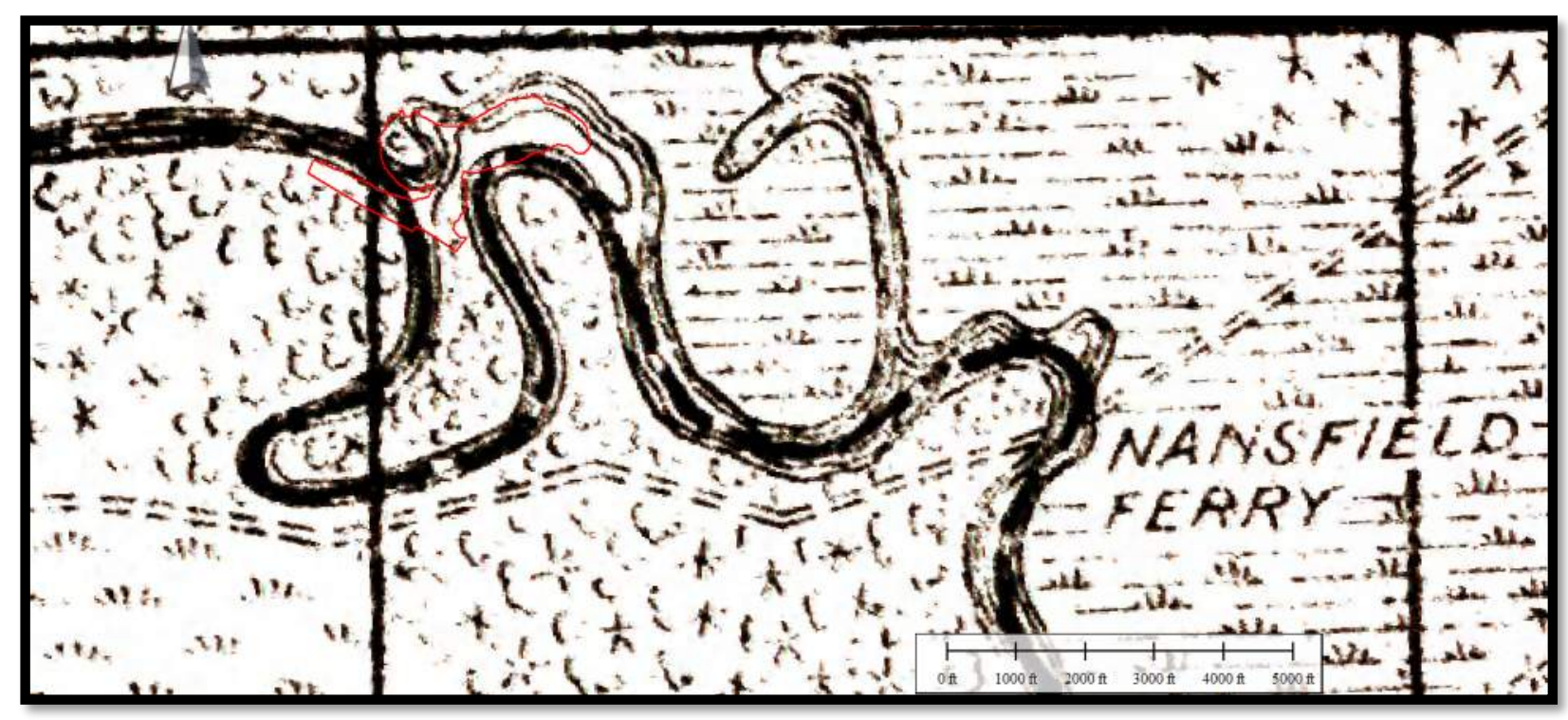

Figure 3: Survey Area in 1911 (U.S. Army Corps of Engineers 1911)

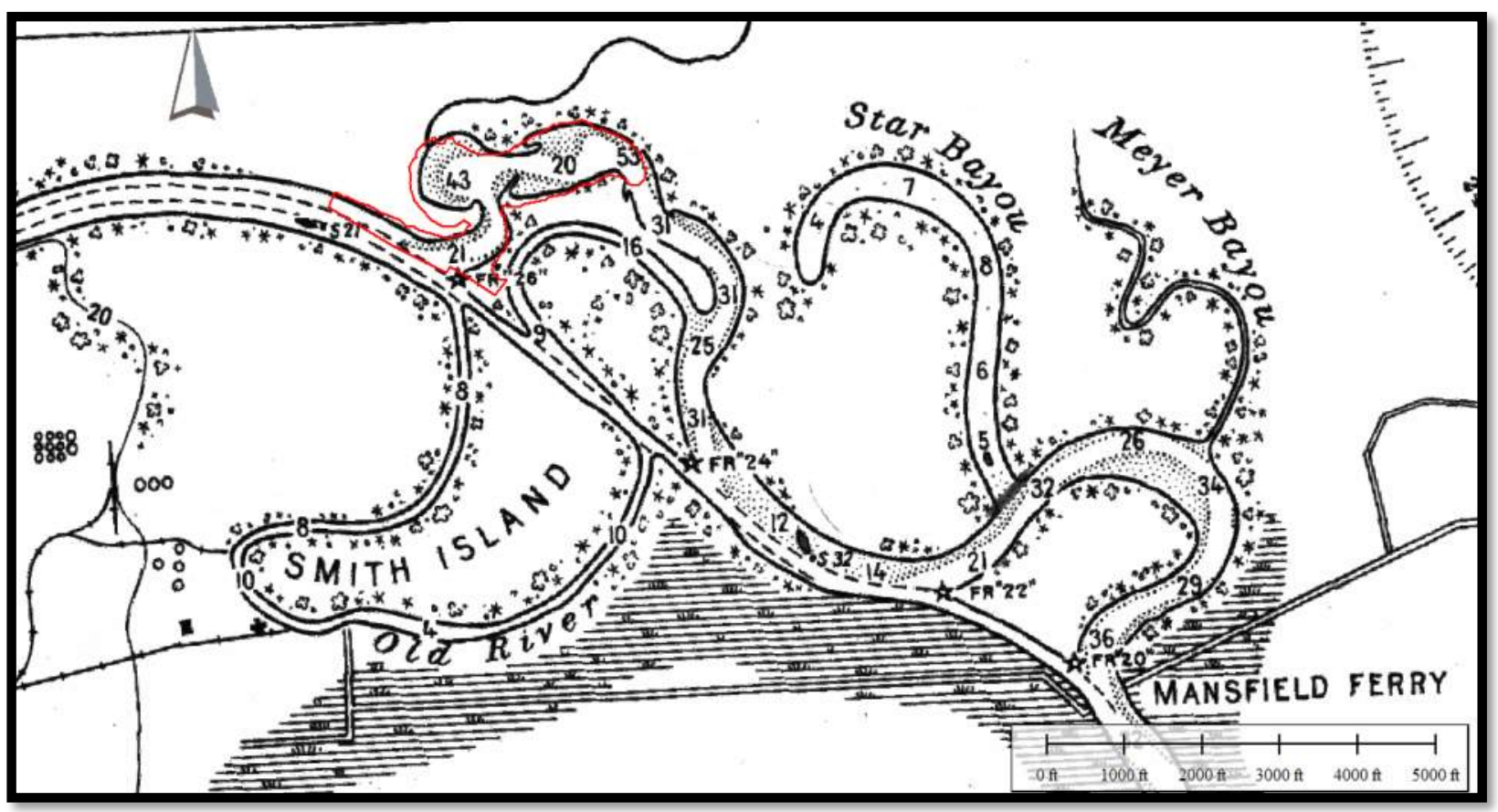

Figure 4: Survey Area in 1926 (United States Coast and Geodetic Survey 1926)

oxbow channel was cut off from the main river channel prior to 1911. The eastern bank of the survey area was once part of a larger Smith Island, which was cut through by the river prior to 1926 (Figure 4).

Substantial portions of the survey area are naturally deep. Figure 4 shows depths as great as 43 and $53 \mathrm{ft}$ in 1926. The project area at the time of the survey ranged in depth (uncorrected for river stage) from 1.5 to $52.5 \mathrm{ft}$ (Figure 5). The passage between the oxbow and the river appears to have shoaled substantially from the $21 \mathrm{ft}$ charted in 1926, but overall, the survey area has changed little since the early 20th century. 


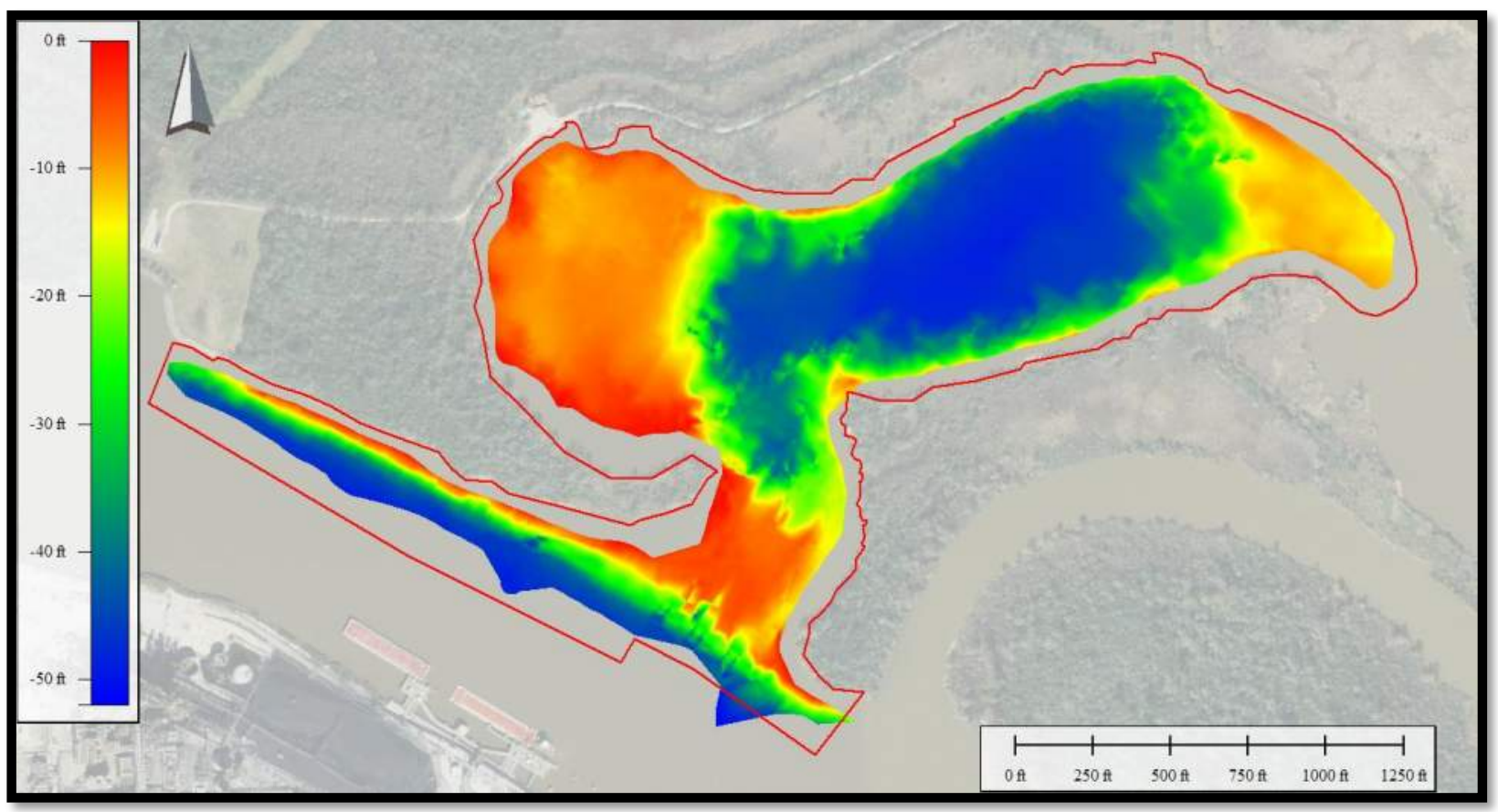

Figure 5: Bathymetry

Base Photo: 2015 DOQQ, top15-nc-cir-50cm-3094642-20150209.jp2

\section{Cultural Background}

\section{Maritime History}

The region surrounding the Sabine and Neches rivers was claimed at various times during its history by both Spain and France. Spanish claims began in 1519, when a Spaniard named Alonso Alvarez de Piñeda led an expedition, on behalf of the governor of Jamaica, to map lands bordering the Gulf of Mexico. Piñeda produced the earliest known map of the Gulf of Mexico showing major inlets along its coast. There is no reliable evidence that he explored inland of the Texas Coast, but, at the least, he demonstrated there was no shortcut to Asia through the Gulf of Mexico (Chipman and Joseph 2010: 24-25).

The first Europeans known to explore the Texas Coast inland were survivors from the shipwrecked Pánfilo de Narváez expedition of 1527. Álvar Núñez Cabeza de Vaca and 80 other Spaniards sailed on rafts to what many believe was Galveston Island. Those who survived the first winter were enslaved by Native Americans. Only four men returned to tell their stories of wandering from tribe to tribe through what is now Texas and northern Mexico to the Pacific Coast, eventually reaching Mexico City after eight years. Cabeza de Vaca published his story in 1542 upon returning to Spain (e.g., Cabeza de Vaca 2013).

In 1539, Hernando de Soto led the first extensive European expedition through what is now the southeastern United States (U.S.). Soto had hopes of finding gold and silver to match that of Central and South America. Instead, he died of a fever after three years of fruitless search, handing over leadership of the expedition to Luis de Moscoso Alvarado shortly before his death. Moscoso led the remnants of Soto's expedition, over 300 men, down the Mississippi River in 1543 and sailed along the Gulf Coast in seven makeshift boats to 
Pánuco. Moscoso's boats may have landed briefly at Sabine Pass to avoid a storm at sea. While ashore, they discovered petroleum floating on the water, which was used to seal their boats. The Soto expedition lost half of its men, failed to find any precious metals, and blazed a path of violence and disease through native populations. Its main accomplishment was expanding Spain's territorial claims in North America (Chipman and Joseph 2010:36-43; Weddle 1991:100).

The Spanish silver fleet, sailing out of Veracruz, conducted steady trade with Havana from the midsixteenth century until 1790 . Their ships typically followed either a northern route, paralleling the coast, or crossed the central Gulf of Mexico. Seasonal changes in wind and current patterns determined their choice of routes (Lugo-Fernandez, et al. 2007). The northern route occasionally imperiled Spanish flotillas when storms pushed them toward the coast. In 1554 a fleet of three Spanish ships wrecked on the Texas Coast about 70 miles south of Mustang Island. Another Spanish ship from Veracruz, El Nuevo Constante, wrecked near the Louisiana Coast, about 75 miles east of Sabine Pass, in 1766 (Pearson and Hoffman 1995).

Loss of the 1554-fleet, including Santa María de Yciar, San Esteban, and Espíritu Santo, led in the short term to an intensive 2-month salvage effort by García de Escalante Alvarado to recover their valuable cargos (McDonald and Arnold 1979). The loss of nearly $300 \mathrm{crew}$ and passengers (only 32 people returned to Veracruz), including women and children, prompted longer range plans for more detailed explorations of the Gulf Coast. Guido de Lavazares was chosen to lead an expedition of three ships with orders to explore the entire coast from Rio de las Palmas to the Florida Keys.

Lavazares arrived on the Texas Coast in the fall of 1558 at the latitude of present-day Kingsville (Chipman and Joseph 2010: 48). From that point, he followed the coast, stopping in what is believed to be Matagorda Bay, where he formally claimed the region as a Spanish possession (Chipman and Joseph 2010:48 and Weddle 1991:100-103). Lavazares continued clockwise along the coast until contrary winds, east of Mobile Bay, forced his return to Veracruz. A second expedition by Gonzalo Gayon followed the Gulf Coast in the opposite direction, from Florida to Texas, within a year or two of Lavazares.

The voyages of Lavazares and Gayon retraced Piñeda's path from four decades earlier and reinforced Spain's claim to the Gulf Coast. Nevertheless, while Spain claimed a vast territory, their population and trade centers were located far to the south and west. The Spanish crown did little to promote exploration or settlement along the northern Gulf Coast, instead focusing on inland expeditions and establishment of missions to Christianize the natives. Ultimately Spain's territory in Texas and the Southeast proved too large and isolated to sustain. It was not until France began to encroach in the region that Spain attempted to reassert control.

In 1682, a French expedition, led by René Robert Cavelier, Sieur de La Salle, traveled down the length of the Mississippi River to its mouth, claiming the Louisiana Territory on behalf of King Louis XIV and France. La Salle was partially following in the footsteps of the Spaniard Moscoso down the lower Mississippi, albeit in a much more deliberative manner. The French territorial claim established by La Salle extended to much of what later became the Louisiana Purchase. La Salle returned to the Gulf Coast by ship in 1685 intent on establishing a permanent colony near the mouth of the Mississippi River. Unfortunately for La Salle and 
his 300 colonists, they missed the Mississippi River and arrived, instead, at Matagorda Bay on the Texas Coast.

By 1686 when Spain heard rumors of a French colony in the heart of their territory, La Salle's Fort St. Louis was already doomed to failure. The expedition lost one of three ships upon their arrival. A second ship soon returned to France with a group of colonists, including La Salle's engineer, Minet, who took with him the first map of Matagorda Bay. Their last ship, La Belle, grounded during a storm in early 1686 and was lost in Matagorda Bay while La Salle was away on an overland expedition, attempting to relocate the Mississippi River. La Salle was murdered by his own men, in a subsequent overland voyage about a year later on March 19, 1687. The location of La Salle's murder likely was between the Navasota and Trinity Rivers in modern Madison or Walker County (Weddle 2001: 214-234). Those colonists remaining at Fort St. Louis, having no way to return to Europe, eventually perished. La Salle, coincidently, had waded ashore near Sabine Pass, while en route to Matagorda Bay, finding the water there so shallow that the crew could not get closer than 300 yards in their shallop (Weddle 2001: 149).

Spain mounted an intensive exploration of the Texas Coast to find and rout out the unwelcome intruders while simultaneously charting their own, relatively unknown, possessions there. Weddle (1991:68) summarized the effect of La Salle's arrival on the Spanish royal court as inspiring "the most intense coastal reconnaissance ever made in the Gulf of Mexico. In five coastal voyages spanning three years, there were few rivers and bays that had not been examined."

An expedition led by Martín de Rivas and Pedro de Iriarte departed Veracruz on December 25, 1686 in search of La Salle. They sailed clockwise along the Gulf Coast with instructions to sail only by day, keep within sight of land, and enter all bays and rivers until they reached the supposed latitude of the reputed Espíritu Santo Bay or the Mississippi River. Along the way, on April 3, 1687, they discovered wreckage of a French ship (La Belle) in Matagorda Bay, which they correctly presumed to have belonged to La Salle. Unknown to Rivas and Iriarte, La Salle had died two weeks before their discovery, and the remnants of his colony were clinging to life only a few miles upstream from them. Alonso de León finally discovered the abandoned remains of Fort St. Louis in 1689 upstream from Lavaca Bay on Garcitas Creek (Weddle 1991: 52-70).

Rivas and Iriarte continued on their expedition, after discovering La Belle, to rule out other locations along the northern Gulf Coast and to find the River "Micipipi" on which the French reportedly were intent upon establishing a settlement. They reached Sabine Pass on April 15, 1687 and described a river of freshwater entering the sea. Soundings of the pass showed only two fathoms of water depth at a distance of one league beyond the river's mouth. The river was believed too shallow to have been entered by La Salle's large ships. Staying only briefly, they traveled on to the Calcasieu River where they discovered a Spanishspeaking native, Pedro the Apalachino, and a young Spaniard from Mexico, Nicolas de Vargas, both survivors from Juan Corso's lost privateer galley. Corso, himself, had been in search of La Salle in hopes of raiding his settlement. Pedro reported that white men had shipwrecked in the next river toward the west (Sabine), and the natives had burned their ship for its iron nails. Thinking that those white men might be remnants either of La Salle's expedition or of Corso's crew, Rivas and Iriarte backtracked for two weeks to further explore Sabine Pass (and Galveston Bay) without finding evidence to support Pedro's story. They 
traveled up the Sabine River half a league and anchored where the river turned northwest, then managed to progress with great care another quarter of a league upstream, until Sabine Lake was in sight, but could go no further, even in canoes (Weddle 1991: 52-70).

La Salle's expedition ended in failure, but his influence reached far into the future. The boundary between Louisiana and Texas remained contentious and shifting for the next century and a half. Spain responded to the French incursion by establishing a network of missions, presidios and settlements in East Texas and Louisiana, 100 to 200 miles upstream from the coast, on the Neches, Sabine and Red rivers, through the first quarter of the eighteenth century (Chipman and Joseph 2010: 106-107). A French soldier named Louis Juchereau de Saint Denis, played a role in international relations in the region. Saint Denis established the French settlement of Fort St. Jean Baptiste de Natchitoches on the Red River in 1714. He was arrested soon after on an expedition to trade with native tribes in New Spain. While under house arrest, he courted and won the hand of a young woman from a prominent Spanish family, the step granddaughter of Commander Diego Ramon, the man who had ordered his arrest. Perhaps as a result of his marriage engagement, he was appointed as part of Ramon's expedition to establish the very missions in eastern Texas that were intended as a bulwark against his countrymen. While he performed a service for Spain, his unique position, no doubt, facilitated trade between French traders and Spanish inhabitants of the region, whose overland supply chain was substantially long (Chipman and Joseph 2010: 102-116).

In 1762, France secretly ceded all of its Louisiana territory to Spain under the Treaty of Fountainebleau following France's loss in the French and Indian War. The following year, King Louis XV "gave" Spain's portion of Louisiana east of the Mississippi River, except New Orleans, to Great Britain as compensation under the Treaty of Paris for France's loss in the Seven Years War on the European continent. Spain did not contest the transfer, since they were able to retain their territory west of the Mississippi (Hoffman 1996:90). As a result, Spain and England were neighboring powers and rivals along the Texas-Louisiana border and Spanish authorities were on the alert for British incursions into Texas.

In 1777, Antonio Gil Ybarbo, a prominent Spanish citizen and rancher near the Sabine River was told by a trader stationed with the Orcoquiza Indians that an English ship, laden with bricks, had stranded in the mouth of the Neches River. Orcoquiza villagers told Ybarbo the Englishmen had first arrived during the summer of 1774 and had planted crops along the Neches. The wrecked vessel had arrived in May of 1777. The cargo of bricks suggests they had planned to construct a substantial structure. Three Englishmen reportedly were left to guard the wreck, but Ybarbo saw no sign of them when he visited the wreck in June of 1777 (Bolton 1915: 424-426; Weddle 1995: 89). Ybarbo's sketch of the wreck location, reproduced in Bolton (1915: 422), suggests the wreck is more likely located at Sabine Pass. That location was confirmed by the journal of Captain George Gauld of the British surveying sloop Florida (Weddle 1995: 149-150). Gauld identifies the wreck as the sloop Robert and says it was bound from Jamaica to the Mississippi River. Three of the nine crew survived and were rescued by the Florida on July 22, 1777, very shortly after Ybarbo's visit.

The Spanish pilot, Jose Antonio de Evia surveyed the Gulf Coast from the Florida Keys to Tampico from 1783 to 1786. Evia camped at Sabine Pass and crossed Sabine Lake to the mouths of the Sabine and Neches rivers. Evia reported the wreckage of a British brigantine at the mouth of Sabine Pass in 1785. Whether this wreck 
was the same as reported in 1777 as the British sloop Robert is uncertain. A sloop has one mast and a brigantine has two, but by 1785 the Robert presumably would have been in a state of severe decay (Block 1976: 12; Hackett 1931: I: 364-367, cited in Enright and Gearhart 2005: 9; McCaslin, et al. 2013: 71).

In 1783, Great Britain, having lost the American Revolutionary War, signed a treaty ceding all British territory east of the Mississippi River to the U.S. This agreement excluded New Orleans and the Mississippi Delta, which remained under Spanish ownership. Spain soon closed the lower Mississippi River and the Port of New Orleans to foreign traffic in an attempt to hinder westward expansion by the U.S. The issue was resolved in 1795 by Pinckney's Treaty, which established a firm boundary between the U.S. and Spanish Florida. Spain retained control of modern Florida and the Gulf Coast east of the Mississippi and south of the 31st parallel. Spain ceded territory north of that line to the U.S. and granted it rights to conduct maritime trade along the entire Mississippi River and to export products through the Port of New Orleans (Chipman and Joseph 2010: 204-229).

Louisiana remained Spanish until 1800 when Spain secretly traded the territory to France in exchange for a portion of Tuscany in Italy. Spain retained nominal control over Louisiana for two years, until the deal was publicly announced in 1802. Within a year, France broke its promise to Spain by selling Louisiana to the U.S. to help finance its looming war with Britain. The transfer of land was not without problems. The border between Spanish Texas and U.S. Louisiana was disputed. Spain claimed land eastward of the Sabine River to the Arroyo Hondo and the Calcasieu River. The U.S. claimed everything east of the Sabine River. Local officials of both nations disregarded the dispute to a large extent, and the area between the Sabine and Arroyo Hondo and Calcasieu, south of the 31st Parallel, became known as the Neutral Ground. Both nations agreed to remove their military from the area to avoid escalating a conflict. As a result, the Neutral Ground became a lawless area rife with smugglers and criminals (Chipman and Joseph 2010: 237-243).

The Adams-Onis Treaty, negotiated in 1819, established the border as the Sabine River; however, the treaty was not ratified until 1821, within months of Spanish Texas becoming part of the short-lived Mexican Empire. The Mexican monarch abdicated in 1823, and the neutral ground, although technically resolved by the Adams-Onis Treaty, was claimed by the First Mexican Republic (also known as the United Mexican States). It was not until the Republic of Texas was formed in 1836 that nations on both sides of the Neutral Ground had friendly relations, thus providing a more stable and predictable environment for economic development of the region. The boundary dispute was laid to rest finally and completely when Texas joined the U.S. in 1845 (Chipman and Joseph 2010: 237-243).

Jefferson County was formed from a Spanish municipality when Texas gained its independence in 1837 with Beaumont becoming its county seat in the following year. Orange County was originally part of Jefferson County but became a separate entity in 1852. Cameron Parish, across the river, was formed from parts of Calcasieu and Vermillion Parish in 1870. It was less developed than the Texas side of the river, in part because it had been Neutral Ground up to about that time, but also because a large proportion of its area is covered by marsh and wetland (even today it is among the largest yet least populated parishes in Louisiana). The earliest settlements in Jefferson County included Santa Anna and Tevis Bluff, which together became Beaumont after the Texas Revolution, Grigsby's Bluff, now Port Neches, and Sabine City, which is now Sabine Pass (Jefferson County Historical Commission 2018). 
Sabine Pass was settled in 1832 by John McGaffey, on a Spanish Land Grant owned by Manuel de los Santos Coy of Nacogdoches. Sam Houston and Philip Sublett, acting as land agents for Coy, promoted the area to investors and created the Sabine Revenue District in 1835. The Port of Sabine was its official point of entry. Houston appointed a collector of customs for the Port of Sabine in 1837. A customs house was built there within a year, and Houston and Sublett began advertising shares to the new town of Sabine City at the Port of Sabine. The town was renamed Sabine Pass in 1839 and was officially incorporated in 1861 (Block 1976: 27-32; Jackson 1930, cited in Hoyt, et al. 1994: 16).

Cattle were traded from Spanish Texas to Louisiana during the 18th century and continued to be the main driver of the local economy through the 19th century. Cattle production declined after 1890, due to a reduction in open range lands, as rice farms, fenced with barbed wire, began to proliferate. Rice production began a rise in Southeast Texas in 1849 due to low prices for corn and cotton. Jefferson and Orange counties were never large cotton producers; however, Sabine City exported significant quantities of cotton that was transported down the river from counties to the north. Other crops grown during the 19th century included corn and sweet potatoes (Jefferson County Historical Commission 2018: 6-7; Block 1976: 33-46, 66-75).

Early maritime commerce on the Neches and Sabine rivers was dominated by keelboats transporting cotton as their principal cargo. Each keelboat might carry 200 bales or more. The boats were relatively inexpensive to build, using a ready supply of local lumber, and required no source of propulsion. Cotton was offloaded to schooners in Sabine Lake for transport to New Orleans. Keelboats often were sold as lumber at Sabine Pass after unloading. Keelboat navigation on the Neches River began in 1830 with a shipment of cotton from Nacogdoches to New Orleans. By 1840 there were, at least, five keelboat crews operating on the lower Sabine River as well (Block 1976: 33-45). Keelboats continued in use after steamboat navigation began. At least one steamboat captain, Robert Patton, was a merchant-planter, owner of two steamboats, Thomas J. Rusk and Angelina, and owner of a keelboat, Rusk. Captain Patton's brother, Moses Patton, was master of the keelboat Rusk on downstream trips and returned upstream on the steamer Angelina with the keelboat in tow (Block 1976: 33-45).

Lumber became the major export from the region in the mid-19th century; although most of it, eventually, was shipped by railroad. Cotton was far more profitable for ships to transport, but lumber was hauled when cotton shipments were unavailable. The first steam sawmill in Jefferson County was built at Sabine Pass, an unforested area, in 1846. Raw logs were rafted down the rivers from their sources, then towed by steamboat through Sabine Lake to sawmills near deep water. By 1857, there were seven steam sawmills in Jefferson and Orange counties, but exports could not keep up with demand from the growing Texas market. A historian of the period noted how strange it was that Texas relied on lumber imports from Mobile, and even Maine, despite having a vast supply of pine in eastern Texas (De Cordova 1858: 39). The rise of railroads in the region was literally fueled by the lumber transportation market. It is telling that the Texas and New Orleans Railroad, so named in 1859, was chartered in 1856 as the Sabine and Galveston Bay Railroad and Lumber Company (Block 1976: 33-46).

Sabine Pass played an active role in supplying the Confederacy during the Civil War. The pass was blockaded by the Union Navy briefly in August of 1861 and then on a permanent basis beginning in July of 1862. The economy rebounded following the Civil War, and the size of steamboats was gradually increasing. The U.S. 
Army Engineers began a series of surveys to ensure that adequate water depths were maintained to ensure safe access as vessel sizes increased. An 1873 survey of the Sabine Pass Bar reported $6.5 \mathrm{ft}$ of water and recommended no need for improvement, as vessels currently trading there were having no trouble in crossing the bar at ordinary low water. Nevertheless, Congress appropriated money for dredging in 1875. Multiple attempts to dredge a 12-ft-deep channel across the bar (about 3.5 miles long) from 1875 through 1881 met with failure. A survey in 1882 showed that the dredged channel was nearly completely filled and recommended construction of jetties prior to dredging further. Work began on the western jetty in 1883 and on the eastern jetty two years later. The east jetty was completed in March 1920. The west jetty was finished in May 1929 (U.S. House of Representatives 1882; Alperin 1977: 62-64).

The petroleum industry exploded onto the local economy in 1901 with the discovery of oil at Spindletop, south of Beaumont. An 8-ft-deep channel, $150 \mathrm{ft}$ wide, was authorized in 1902 to facilitate bringing oil to market. The channel was dredged from Sabine Pass to the mouths of the Neches and Sabine rivers, at the upper end of Sabine Lake. The Sabine-Neches Navigation District was formed in 1909. Since then there have been numerous projects to both widen and deepen various segments of the SNWW. The channel is presently maintained, since 1962, at a depth of $40 \mathrm{ft}$ from Beaumont through the Outer Bar (Alperin 1977: 65-80).

The lumber industry remained strong past the end of the century. Evidence of the lumber industry remains visible today just a few hundred feet north of the survey area (Figure 6). Logs were pulled by cables to the river, by way of canals where necessary, leaving large radial patterns of drag scars on the landscape. Once logs reached the river, they were rafted downstream to sawmills. Teal (1973, cited in Hoyt, et al. 1994: 20) states that the last log raft was sent down the river in 1911. The canals in Figure 6 were excavated prior to 1932 , suggesting that the area was logged prior to that date (U.S. Geological Survey 1932). The process of logging by steam is described in a detailed industry publication by the Lidgerwood Manufacturing Company (1905).

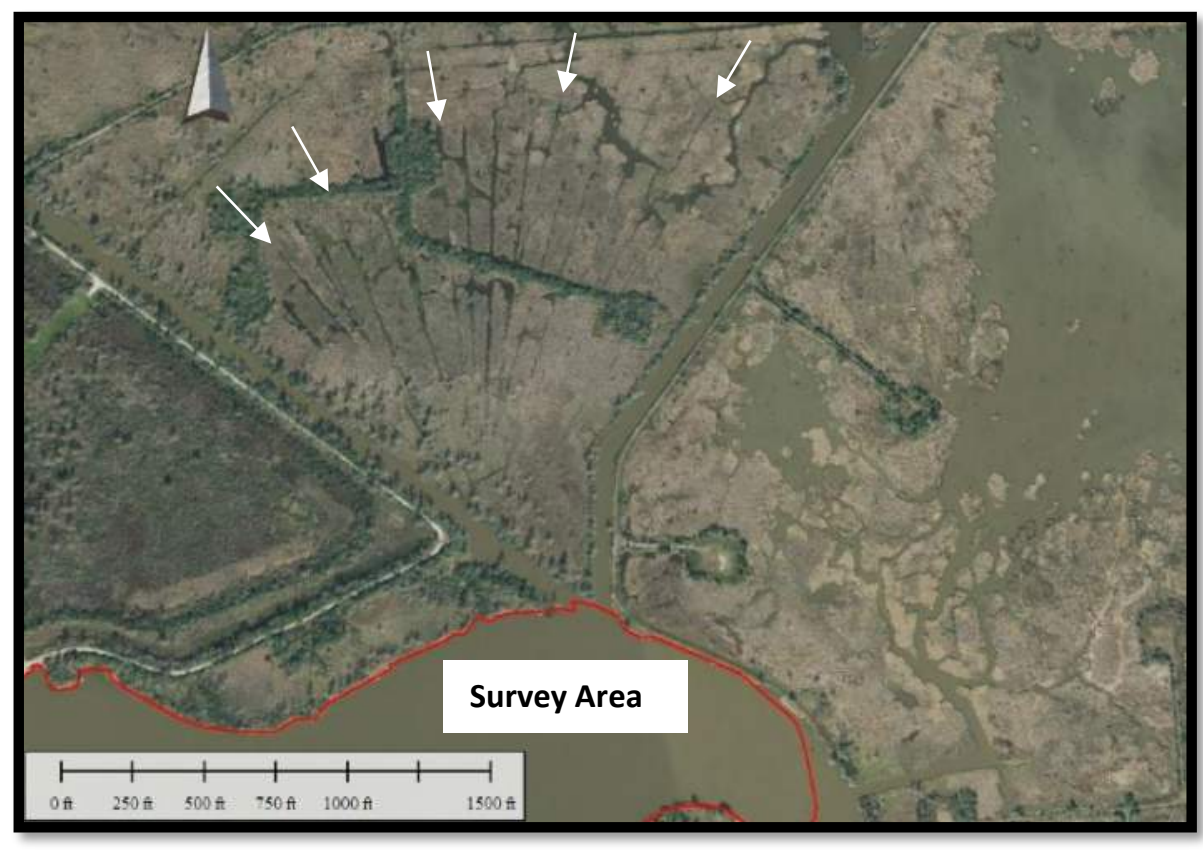

Figure 6: Logging Scars North of the Survey Area (arrows) 
The lumber industry also supported a wooden shipbuilding industry, which lasted through World War I. A large number of wooden transport ships were constructed at local shipyards during the war under contract with the Emergency Fleet Corporation as authorized by the U.S. Shipping Board. Interestingly, the largedimension lumber required for their construction was no longer locally available in sufficient quantity to complete the contracts and had to be shipped from the Pacific Northwest. Many of these ships were abandoned in the Neches River upstream of Beaumont and in the Sabine River near Orange following the war (Hoskins, et al. 2007: 9-22).

\section{Potential for Historic Shipwrecks}

Europeans have navigated the Texas Coast, including the area offshore of Sabine Pass, for the past 500 years. Remnants of Hernando de Soto's expedition likely entered Sabine Pass in 1543 long enough to wait for a storm to pass and seal their leaking boats. Spanish merchant ships occasionally sailed by on their way from Veracruz to Havana over the next 250 years. One of these ships, El Nuevo Constante, wrecked during a storm, in 1766, about 75 miles east of Sabine Pass (Pearson and Hoffman 1995). Two decades later, La Salle stopped briefly to investigate the vicinity of Sabine Pass during his failed search for the Mississippi River. The water there was so shallow that the crew could not get closer than 300 yards in their shallop (Weddle 2001: 149). Rivas and Iriarte traveled up the Sabine River to within sight of Sabine Lake during their search for La Salle's colony in 1687 (Weddle 1991: 60).

Visits to Sabine Pass increased after 1685 as Spain and France competed over domination of the region. The first collector of customs was appointed at the Port of Sabine Pass in 1837, the same year that the river was opened for steam navigation by clearing of log jams. The volume of trade through Sabine Pass and on the rivers would have steadily grown from then onward, as the region became part of the Republic of Texas and, soon afterward, the U.S. Jetty construction was started during the 1880s, and the first successful channel improvements were completed in response to the Spindletop oil boom in 1902 . Since then, the safety of commercial traffic would have continually improved due to a system of channels maintained at suitable depths and marked by navigational aids.

Improvements to channels coincided with steady advancements in the safety of ships during the first half of the twentieth century. Sailing vessels were being replaced rapidly by safer, machine-powered vessels. By 1910, sailing ships comprised less than half of annual losses of U.S. merchant vessels for the first time, and by the end of World War II, only 2-percent of nationwide losses were sailing ships. This is significant, because sailing ships were at a higher risk of running aground than machine-powered vessels. At the same time that machinery was replacing wind power, more durable metal hulls gradually were replacing wooden hulls, a trend which had accelerated by the turn of the century. Nevertheless, at least 93 percent of all U.S. merchant vessels lost through the end of World War II were made of wood (Gearhart 2011a). Some sailing vessels were converted to barges and used for a few more years on inland waterways as machine-powered boats replaced them. Watercraft often were abandoned as they fell out of commercial service. Abandonment was common in backwater areas, including river bayous, where ships would not obstruct navigation.

Shipwrecks reported within 3 miles of the various survey areas are included in Table 1. Sources consulted for Table 1 include the THC's Texas Archaeological Sites Atlas (Atlas); the National Oceanic and 
Atmospheric Administration's (NOAA) Automated Wreck and Obstruction Information System (AWOIS) database; a shipwreck database compiled by PBS\&J; historic maps from the Texas Historical Overlay (Foster, et al. 2006); Hoyt, et al. (1994: 23-24, Table 1); and Enright and Gearhart (2005: 22-23, Table 1). The THC Atlas contains reports of shipwrecks from historic records. The AWOIS database is maintained by NOAA to support the charting of coastal areas. AWOIS tends to report recent shipwrecks; however, some historic wrecks are included. Positions for wrecks in AWOIS are usually more accurate than those from historic records, although positions pre-dating the era of satellite position systems can vary considerably from actual locations. A group of archaeologists, including this author, assembled the PBS\&J database, in part, based on information gathered from charts, historical reports, THC files, AWOIS, and U.S. Department of the Treasury (1906-1946). The PBS\&J database focuses primarily on well-documented commercial wrecks postdating 1850.

At least 7 shipwrecks have been reported within 3 river miles of the survey area (Table 1 ) by one or more of the sources listed above. Positions reported in historical accounts are often imprecise, and archaeologists have yet to record any of the wrecks listed in Table 1.

Table 1: Wrecks Reported Within Three River Miles of Survey Area

\begin{tabular}{|c|c|c|c|c|}
\hline Name & $\begin{array}{l}\text { THC } \\
\text { No. }\end{array}$ & $\begin{array}{l}\text { AWOIS } \\
\text { No. }\end{array}$ & Date Sunk & Description \\
\hline Laura & 2375 & - & $1890 \mathrm{~s}$ & river steamer \\
\hline Tom Parker & 2409 & - & 1880 & river steamer \\
\hline Unknown & - & - & pre-2014 & $\begin{array}{l}\text { wreck awash symbol on current } \\
\text { NOAA Electronic Navigation Chart } \\
\text { (ENC) } 11343\end{array}$ \\
\hline Unknown & - & - & pre-2014 & $\begin{array}{c}\text { wreck awash symbol on current } \\
\text { NOAA ENC } 11343\end{array}$ \\
\hline Unknown & - & - & pre-2014 & $\begin{array}{c}\text { visible wreck symbol on current } \\
\text { NOAA ENC } 11343\end{array}$ \\
\hline Unknown & - & - & pre-2014 & $\begin{array}{c}\text { visible wreck symbol on current } \\
\text { NOAA ENC } 11343\end{array}$ \\
\hline Unknown & & 13615 & c. 2002 & AWOIS \\
\hline
\end{tabular}

\section{Factors Affecting Vessel Loss}

Factors contributing to the loss of watercraft vary depending on environmental conditions. Historic government statistics, summarized by Gearhart, et al. (1990: Volume IV, 59-61), categorized vessel casualties, including most accidents and incidents resulting in injury or loss of property, and reported the value of losses incurred. A total loss was reported if the hull could not be saved. These statistics do not reflect the degree to which cargo and vessels were salvaged. Types of casualties included foundering, stranding, collision and other (including fires, boiler explosions, injuries, and mechanical failures, etc.).

Foundering was the primary mechanism of vessel loss in navigable waters. The Annual List of Merchant Vessels of the United States (U.S. Department of the Treasury 1906-1946) defined foundering as leaking or capsizing of vessels. Foundering accounted for about 6 percent of historic vessel losses. Despite its low 
rate of occurrence, recovery from foundering was less likely than from any other type of casualty. Fiftyfour percent of all foundered vessels were reported as totally lost.

Stranding was the primary mechanism of loss in shoal waters and was, by far, the most common type of shipwreck during the historic period. Stranding (or grounding) accounted for 64 percent of total losses reported by the U.S. Lifesaving Service for the period 1876 through 1914 (Gearhart, et al. 1990: Volume IV, 59-61). Stranding occurred where the water was too shallow for navigation, including shorelines, harbor bars and reefs. Forty-six percent of stranding events resulted in a total loss.

Severe weather accounted for 55 percent of total losses reported by the U.S. Lifesaving Service from 1876 through 1914. Almost half of all losses from foundering were caused by weather, compared with two thirds of losses from stranding. Mariners had short warning of approaching storms prior to modern weather forecasting. The Gulf Coast can experience hazardous weather conditions throughout much of the year. Hurricane season lasts from late June through October. Hurricane-force winds can devastate ships caught unprepared. During the winter, severe cold fronts, or Northers, with winds exceeding 50 miles per hour and dangerous waves can affect the Gulf Coast.

Intentional abandonment of watercraft due to age was not considered accidental loss, so statistics are unavailable. Nevertheless, intentional abandonment is a significant source of sunken historic watercraft, especially in backwater environments where commercial navigation would be relatively unobstructed. The survey area would have been an attractive location for abandonment of decommissioned watercraft, after the oxbow was formed.

\section{Factors Affecting Vessel Preservation}

Preservation of sunken watercraft depends mainly upon their composition and the extent of their burial. Vessels may become partially buried soon after sinking due to the combined effects of current scour, liquefaction of sediments, and their weight pressing down on a waterlogged substrate. Ships made of metal are equally susceptible to burial as wooden hulls, but metal hulls remain exposed much longer than wooden ones in saline waters along the Gulf Coast.

Fresh and/or cold water can substantially extend the life of wood exposed in the water column. Exposed wooden components tend to disintegrate quickly where wood-boring organisms thrive. Biological organisms and water saturation weaken the wood, which is then more easily disarticulated and laid flat or removed by fishing trawlers, strong currents, and storm waves. Burial promotes long-term preservation of wood by creating an oxygen-deprived environment, which limits biological activity. Given a sufficient quantity of weakly-consolidated sediment, a significant portion of a hull might be preserved beneath the mudline.

Iron corrodes five times faster in seawater than when buried on land. Iron artifacts tend to become concreted when calcium carbonate from the seawater cements adjacent materials, such as rock and sand, or even other artifacts, to the iron object. Prolonged oxidation can leach out most or all iron mineral, leaving only a carbonate mold of the original artifact (Hamilton 2010). Iron and steel hulls, nevertheless, can survive seawater exposure for well over a century. 


\section{Previous Investigations}

Three marine archaeological surveys are reported within 3 miles of the survey areas (Table 2). The U.S. Army Corps of Engineers contracted with PBS\&J for a survey of the SNWW in 2003 (Enright and Gearhart 2005). PBS\&J's survey encompassed 3,310 acres in Texas and 329 acres in Louisiana, including the Outer Bar Channel, the Sabine Pass Jetty Channel, the Sabine Pass Channel, the Port Arthur Canal, the SabineNeches Canal, and the Neches River Channel. PBS\&J recommended avoidance of 29 geophysical targets, considered to be potential historic properties. That number included 27 newly discovered targets, as well as two targets previously recommended for avoidance by Hoyt and Schmidt (1997). Targets that could not be avoided were recommended for further archaeological investigations in the form of close-order geophysical surveys to aid differentiation between anomalies requiring diver assessments and those associated with debris.

Table 2: Previous Marine Investigations Within 3 River Miles of the Survey Area

\begin{tabular}{|c|c|c|c|c|}
\hline $\begin{array}{l}\text { Antiquities } \\
\text { Permit }\end{array}$ & $\begin{array}{c}\text { Principal } \\
\text { Investigator }\end{array}$ & Report Title & $\begin{array}{c}\text { Contractor and } \\
\text { Sponsor }\end{array}$ & Reference \\
\hline 3061 & $\begin{array}{l}\text { Jeffrey } \\
\text { Enright }\end{array}$ & $\begin{array}{l}\text { Historic Properties Identification, } \\
\text { Oyster Reef Identification, and } \\
\text { Pipeline and Obstruction } \\
\text { Identification for the Sabine/Neches } \\
\text { Waterway Widening and } \\
\text { Deepening, Jefferson and Orange } \\
\text { Counties, Texas, and Cameron } \\
\text { Parish, Louisiana }\end{array}$ & $\begin{array}{l}\text { PBS\&J for U.S. } \\
\text { Army Corps of } \\
\text { Engineers }\end{array}$ & $\begin{array}{l}\text { Enright } \\
\text { and } \\
\text { Gearhart } \\
(2005)\end{array}$ \\
\hline 5546 & $\begin{array}{l}\text { Charles } \\
\text { Pearson }\end{array}$ & $\begin{array}{l}\text { Results of a Cultural Resources, } \\
\text { Remote-Sensing Survey in Star } \\
\text { Bayou, Orange County, Texas }\end{array}$ & $\begin{array}{l}\text { Coastal } \\
\text { Environments, } \\
\text { Inc. for E. } \\
\text { Arnaud }\end{array}$ & $\begin{array}{l}\text { Pearson } \\
(2010)\end{array}$ \\
\hline 8418 & $\begin{array}{l}\text { Robert } \\
\text { Gearhart }\end{array}$ & $\begin{array}{l}\text { Marine Archaeology Assessment, } \\
\text { Sabine-Neches Waterway Channel } \\
\text { Improvement Project, Jefferson and } \\
\text { Orange Counties, Texas and } \\
\text { Cameron Parish, Louisiana }\end{array}$ & $\begin{array}{l}\text { BOB } \\
\text { Hydrographics, } \\
\text { LLC for Perennial } \\
\text { Environmental } \\
\text { Services, LLC }\end{array}$ & $\begin{array}{l}\text { Gearhart } \\
\text { (2019) }\end{array}$ \\
\hline
\end{tabular}

Coastal Environments, Inc. completed a small marine geophysical survey for a proposed dredging project in Star Bayou in 2010. Star Bayou is an oxbow channel of the Neches River, similar to the present study area. The project was performed under Texas Antiquities Permit 5546. The abstract and report are not available on the THC Atlas (Pearson 2010).

BOB conducted a marine archaeological assessment in support of the Sabine-Neches Waterway Channel Improvement Project. The scope of archaeological assessments included: survey of new Offshore areas proposed for dredging; close-order survey of Offshore and Inshore targets, including Target TB8.1 near the proposed South Terminal; survey of two proposed turning basins on the Neches River; dive investigations of selected targets; and survey of Taylor's Bayou. Surveys were performed in 2018 and 2019 
by DoC Mapping, LLC. Dive investigations were completed in 2019 by Triton Diving Services, LLC. BOB archaeologists, working under Texas Antiquities Permit 8418, monitored all geophysical data acquisition and diving operations. Archaeological recommendations for avoidance remain in effect for six targets, all located downstream from Sabine Lake and/or offshore.

\section{Research Design}

\section{Survey Methods}

The purpose of the survey was to map geophysical anomalies that might indicate the presence of historically-significant, submerged archaeological sites. Submerged archaeological sites, in this context, might be historic sites, such as sunken or abandoned watercraft. The primary instrument for locating submerged watercraft in buried contexts is the magnetometer. Exposed shipwrecks are most easily recognized in side-scan sonar imagery. Geophysical survey of the study area was designed to meet or exceed the following minimum standards of the THC for archaeological survey of state-owned submerged lands (Texas Administrative Code, Title 13, Part 2, Chapter 28, Rule 28.6): 1) the survey must be conducted under a Texas Antiquities Permit issued by the THC; 2) the survey line interval cannot exceed $20 \mathrm{~m} ; 3$ ) bottom-disturbing activities must be avoided within $50 \mathrm{~m}$ of potentially significant targets; 3 ) the survey area must extend beyond the limits of bottom-disturbing activities by the width of the avoidance margin; 4) survey instrumentation must include a marine magnetometer, a high-resolution side-scan sonar, and a recording fathometer all of which must record data digitally to electronic storage media; 5) survey instrumentation should be interfaced with a positioning system having accuracy comparable or better than a differential global positioning system (GPS) receiver; 6 ) the magnetometer must be towed within $6 \mathrm{~m}$ of the marine bed and should sample at least once per second; 7) the side-scan sonar should operate at a minimum frequency of 300 kiloHertz; 8) the positioning system should sample at least once per second; and 9) no artifact collection is permitted.

The survey area totaled 78 acres. A 20-m transect interval was completed for the entire survey. Additional transects were completed at a 10-m interval, considered close-order survey, over shallow portions of the area as time permitted during the initial survey. The survey was extended $50 \mathrm{~m}(164 \mathrm{ft})$ beyond the anticipated top of the channel slope, as required by the THC for inshore marine projects. The initial geophysical survey was completed by BOB from June 10-13, 2019. Additional close-order magnetometer survey was conducted on August 29, 2019 over one deep anomaly while in the field probing two other anomalies. The archaeological field crew, responsible for geophysical data acquisition, included Robert Gearhart (PI) and Ed Baxter. Geophysical data was acquired from BOB's 20-ft, aluminum survey vessel.

Vector data, including sensor positions, bathymetry and magnetometer, were logged in Hypack software. Side-scan sonar data was logged in Edgetech's Discover software. Geographic positions and heading were acquired using a Hemisphere VS330 GPS. A Geometrics 882 magnetometer, equipped with an altimeter and depth finder was towed within $20 \mathrm{ft}$ of the mudline. The magnetometer sensor was floated on the surface $15 \mathrm{~m}$ behind the survey vessel in areas less than $20 \mathrm{ft}$ deep. Sensor floats were removed and cable length was increased to $25 \mathrm{~m}$ when towing the magnetometer in water deeper than $20 \mathrm{ft}$ to keep the sensor close to the bottom. 
Bathymetry and side-scan sonar data were acquired with a pole-mounted, Edgetech 6205 system operating at a frequency of 550 kiloHertz. Sonar motion was corrected using an iXBlue Octans 3000 system. Geographic positions were embedded in the digital sonar data as it was recorded. Sonar range was set to $25 \mathrm{~m}$ to ensure sufficient overlap with adjacent swaths. Chesapeake SonarWiz software was used to combine sonar data from each transect into a composite sonar mosaic.

\section{Interpretation of Magnetometer Data}

Low-frequency fluctuations in magnetic data caused, for example, by diurnal passage of the sun or by geologic gradients were removed, prior to contouring, using a filter algorithm. The algorithm treats shortterm fluctuations, exceeding a selected threshold amplitude of $0.5 \mathrm{nT}$ as anomalous values. The result is a dataset in which abnormally high and low magnetic amplitudes (anomalies) are centered around zero (representing the ambient level). All amplitude shifts, smaller than the threshold value, are reduced to near zero and are treated as ambient background. This process removes low frequency data, leaving potentially significant anomalies intact, and allows a visual representation of anomaly polarity.

Magnetometer data illustrated in this report have been thinned to a 1-second interval between data points. Diurnally-corrected magnetometer data was contoured using Blue Marble's Global Mapper software (Version 17.2) at a 5-nT contour interval. Magnetic amplitudes between $+5 \mathrm{nT}$ and $-5 \mathrm{nT}$ are considered insignificant. Contour maps omit the 0-nT contour level to prevent a cluttered appearance. Positive amplitude is indicated by red contours, and negative amplitude is drawn as blue contours.

Most magnetic anomalies in marine environments are caused by relatively small pieces of ferromagnetic debris, which tends to concentrate near high-traffic areas, marine disposal areas, industrial developments, petroleum wells, and pipelines. The frequency of ferromagnetic debris far outnumbers shipwrecks, necessitating some means for distinguishing between the two when conducting archaeological assessments. The method used here is based primarily upon a study by Gearhart (2011b) that compared shipwreck and debris anomalies. Gearhart has analyzed magnetic data from a large and diverse collection of anomaly sources, including 39 verified shipwrecks (Gearhart 2011b, 2016) and many debris sources with the goal of characterizing differences between these two categories of magnetic sources. Shipwrecks in his dataset represent a broad spectrum of material compositions, construction styles, ages, and archaeological contexts. Their hulls include construction from wood, iron, steel, and concrete. Their propulsion systems range from sail to steam-driven paddlewheels and propellers, and from oil and diesel screws to towed or pushed barges. They range in age from the mid-16th to the mid-20th century. They have been found in diverse depositional environments including harbor entrances, surf zones, beaches, marsh, oyster reefs, open bay waters, and the Gulf of Mexico. And this assortment of watercraft found their way to the seafloor in various ways including stranding on beaches, foundering at sea, by fire, by explosions (both accidental and intentional), and by abandonment. Some were partially demolished or salvaged after wrecking. Others remain largely untouched since the day they sank. Yet despite their many differences, they share common characteristics, which form the basis for this interpretative method.

\section{Role of Sonar Imagery}

Anomaly sources exposed at the seafloor can be detected by side-scan sonar, which may, on occasion, be useful for determining their identity. For example, a straight, narrow, linear sonar target might be 
interpreted as a pipe. A pipe interpretation becomes more likely if that target is situated along the central axis of a linear anomaly pattern. On the other hand, if that same sonar target is not associated with a magnetic anomaly, one might interpret, instead, a tree or anchor scour. More often than not, sonar targets are unreliable indicators of magnetic source identity, but sonar occasionally provides unambiguous verification. Sonar also can aid magnetic interpretations because of what it does not show. For example, a magnetic anomaly without a corresponding sonar target, in Texas coastal (saline) waters, is not likely associated with a shipwreck having either a metallic hull or a machine-powered propulsion system, except in areas of high sediment accretion.

Shipwrecks with metal hulls are usually exposed on the seafloor, thus tend to be fairly obvious on a sonar image. Gearhart (2011a) reported that 100 percent of shipwrecks $(n=74)$ discovered by BOEM-regulated geophysical surveys in shallow, Gulf of Mexico waters (less than $600 \mathrm{ft}$ deep) appear on side-scan sonar imagery. About one third of that number are confirmed to have metal hulls. The rest are presumed to be metallic, simply because their ship-shaped structures are preserved in the water column. By comparison, only 7 wood-hulled wrecks were known to BOEM from the same area up to that time, but none of those were discovered by geophysical surveys, despite the fact that wood-hulled wrecks in the U.S., pre-dating World War II, are 13 times more abundant than metal-hulled wrecks (Gearhart 2011a). Wrecks of woodhulled sailing ships, in Texas bays and adjacent coastal waters, are usually buried, thus they typically have no sonar target. Shipwrecks with wooden hulls and machine-powered propulsion systems might appear on sonar or might not. Lower portions of the wooden hull itself would tend to bury, but steam machinery is large and may remain exposed above the seafloor. Gas- and diesel-powered machinery tends to be smaller thus might be more easily buried than steam machinery.

\section{Amplitude}

Anomaly amplitude correlates poorly with horizontal dimensions of a magnetic source, because amplitude depends greatly upon the mass of the source and the distance between the magnetometer and the source. Small sources can produce large amplitude when measured at close range. Shipwreck anomalies from Gearhart (2011b) have average peak-to-peak amplitudes of $270 \mathrm{nT}$ for wood-hulled sailing vessels $(n=8) ; 5,020 \mathrm{nT}$ for wood-hulled machine-powered vessels $(n=7)$; and 10,386 nT for iron- and steel-hulled vessels ( $n=12$ ). Magnetic debris can produce amplitudes virtually anywhere within that same range; thus, amplitude is of little use for differentiating shipwrecks from debris.

\section{Complexity}

Archaeologists frequently have described shipwreck anomalies as appearing "multicomponent" or "complex", while anomalies having simple, monopolar or dipolar shapes often were attributed to debris. Garrison, et al. (1989: II, 223) summarized several common methods for prioritizing anomalies with a focus on complexity. Shipwreck anomalies were characterized as having: multiple peaks of differing magnitudes spread over an area greater than 10,000 square meters (2.5 acres); gentle gradients; and a linear association with anomalies on adjacent transects. A typical debris anomaly was characterized as having a single peak covering an area of less than 10,000 square meters, a steep gradient, and no alignment of anomalies on adjacent lines. 
Some early observations of complexity in wreck anomalies pre-dated computer contouring software. One or more peaks were observed on each transect crossing a single anomaly, but the spatial relationships between those peaks were not apparent. This problem was compounded by the lower accuracy of positioning systems prior to GPS. Thus, even a simple dipole might appear more complex than it really was. Earlier magnetometer technology also might have contributed to the perception of complexity. Proton precession systems tended to produce false noise spikes in the presence of high magnetic gradients, which could be interpreted as complex patterns of amplitude peaks where none existed.

A collection of 39 anomalies from verified shipwrecks reported by Gearhart (2011b and 2016) indicate, contrary to earlier models, that shipwreck anomalies (in mid-northern latitudes) tend to be dominated by a single main dipole, oriented approximately in line with magnetic north (Figure 7, for example; also see "Orientation" below). In fact, most debris anomalies also tend toward simple, dipolar shapes, while some shipwreck anomalies have more than two amplitude peaks. The concept of complexity is insufficient, by itself, to differentiate shipwrecks from debris anomalies; although, this fact does not lessen the need to correct any remaining misconceptions that shipwreck anomalies are typically complex and debris anomalies are not. The truth is more complicated than that simple dichotomy.

Many wreck anomalies also have secondary amplitude peaks, in addition to their main, north-southaligned dipole. Secondary peaks typically have lower amplitude than the main dipole and cover a smaller area than the main dipole peaks in all examples known to this author. Secondary peaks can be caused in two ways. The combined mass of the wreck either induces secondary peaks, or they are directly associated with individual ferromagnetic sources in a debris field.

Secondary peaks can be induced by the magnetic field lines emanating from wreckage. In mid-northern latitudes, a smaller peak sometimes occurs immediately north or south of, and in line with, the main dipole (e.g., peaks labelled " $A$ " in Figures 8, 9, and 10). Amplitude peaks of this nature are not necessarily located over an anomaly source and may not indicate the presence of widely-scattered wreckage. Rather they seem to be induced by a source of relatively high mass, such as a ferrous hull. In such cases, magnetic lines-of-force can loop so far to the north and/or south of a source that, respectively, they reinforce or diminish (i.e., are anomalous to) earth's field. The result is a small positive peak to the north and, occasionally, a smaller negative peak to the south of the main dipole. They will always have polarity opposite the adjoining peak of the main dipole. Such peaks are fairly symmetrical about an anomaly's north-south axis and will not overlap its main dipole. The inflection point between an induced secondary peak and the main dipole occurs where the anomaly's lines of magnetic force are perpendicular to earth's lines of force.

Other secondary peaks may be directly caused by relatively large, individual magnetic sources within or near a hull or debris field. If such a mass is sufficiently large, its anomaly might not be completely cancelled by neighboring sources, allowing it to stand out. A similar effect may be observed if a magnetometer 

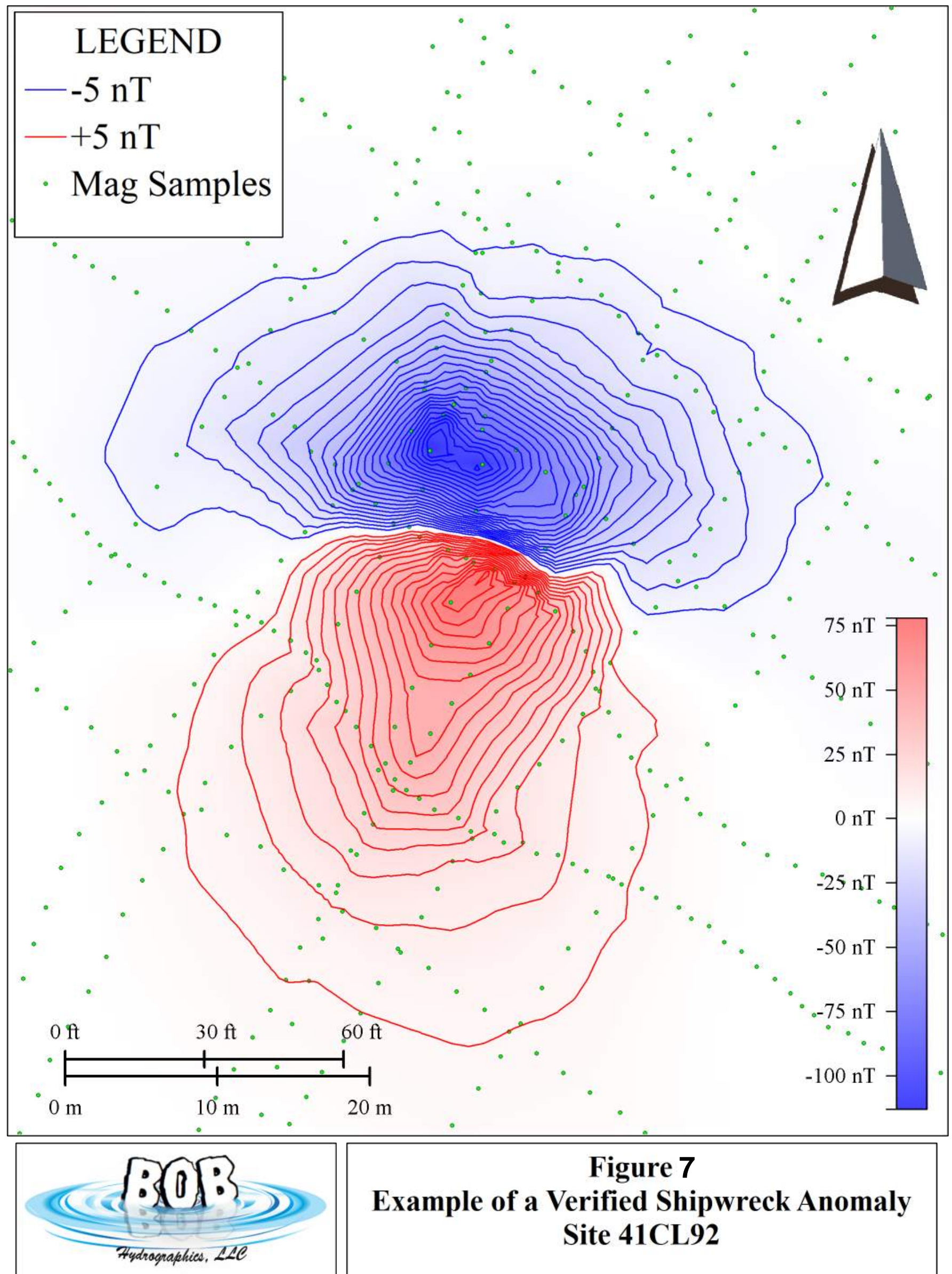

Figure 7

Example of a Verified Shipwreck Anomaly Site 41CL92 
passes sufficiently close to a complex source, such as a shipwreck, so that some large-mass sources, are individually expressed against the background of the main dipole field. Such debris-centric, secondary peaks should have random orientations and positions, with respect to the main dipole, since they are directly caused by randomly-positioned objects within a debris field. They may overlie and disrupt the symmetry of the primary north-south dipole (e.g., peaks labelled "B" in Figures 8 and 10).

\section{Horizontal Dimensions}

Anomaly width, or duration as preferred by some, is a common and valid measure used by archaeologists for discriminating potential shipwreck anomalies from those believed more likely caused by debris. For example, Linden and Pearson (2014) would consider an anomaly significant if it has amplitude of at least $50 \mathrm{nT}$ and a width of $65 \mathrm{ft}$ or more. The horizontal dimensions of shipwreck and debris anomalies overlap considerably, especially when considering wrecks with wooden hulls, thus width alone is not particularly useful for discriminating between the two. There is a 15 -fold difference in width between the smallest wood-hulled sailing ship and the largest steel tanker, so large wrecks tend to be obvious. Unfortunately, small, wooden watercraft, even many steamboats, tend to have anomalies no wider than many debris anomalies.

Small shipwreck anomalies cannot be distinguished from debris anomalies based on size alone. All wooden-sailingship anomalies and all but one wooden-steamboat anomaly known to this author are smaller than 10,000

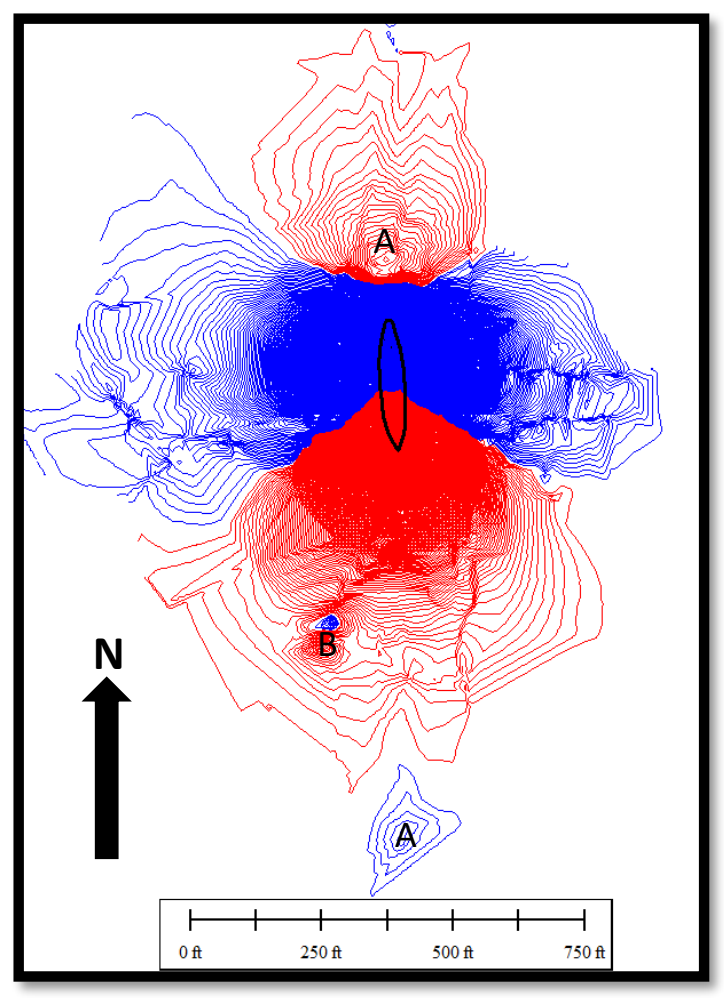

Figure 8: City of Waco Anomaly (iron hull) square meters, Garrison, et al.'s (1989: II, 223) minimum suggested size for typical shipwreck anomalies. Site 41CL92 (Figure 7), for example, covers an area of only 1,580 square meters ( 0.4 acres) out to the 5 nT contour. Small, wooden, and generally historic, shipwrecks are the most difficult sites to detect precisely because their anomalies overlap in size with many debris anomalies.

The smallest wreck, although not the smallest anomaly, in Gearhart's anomaly dataset, Mag-13 (Figure 11 ), is a wooden hull buried 2-10 ft below the seafloor. The hull measures roughly $35 \times 13 \mathrm{ft}$, based on diver probes (Gearhart 2016). The Mag-13 anomaly measures 197 x $164 \mathrm{ft}(60 \times 50 \mathrm{~m})$ across. Site 41CL92 (Figure 7), although having larger site dimensions, has the smallest verified wreck anomaly known to this author, measuring $176 \times 155 \mathrm{ft}(53.6 \times 47.2 \mathrm{~m})$ to the 5-nT contour. Divers identified Site 41CL92 as an early 19th-century sailing vessel containing a large collection of concreted artifacts, iron bar stock, and pig iron ballast but with no hull remaining (Borgens 2004). Its debris field measures $52 \times 23 \mathrm{ft}(15.9 \times 7 \mathrm{~m})$ across. 
The 41CL92 anomaly is smaller than the Mag-13 anomaly, even though the 41CL92 site dimensions are larger. Its smaller magnetic footprint might be due to its disarticulated nature, whereas the Mag-13 site appears to have an intact hull. The higher entropy of a disarticulated wreck, in theory, should result in a

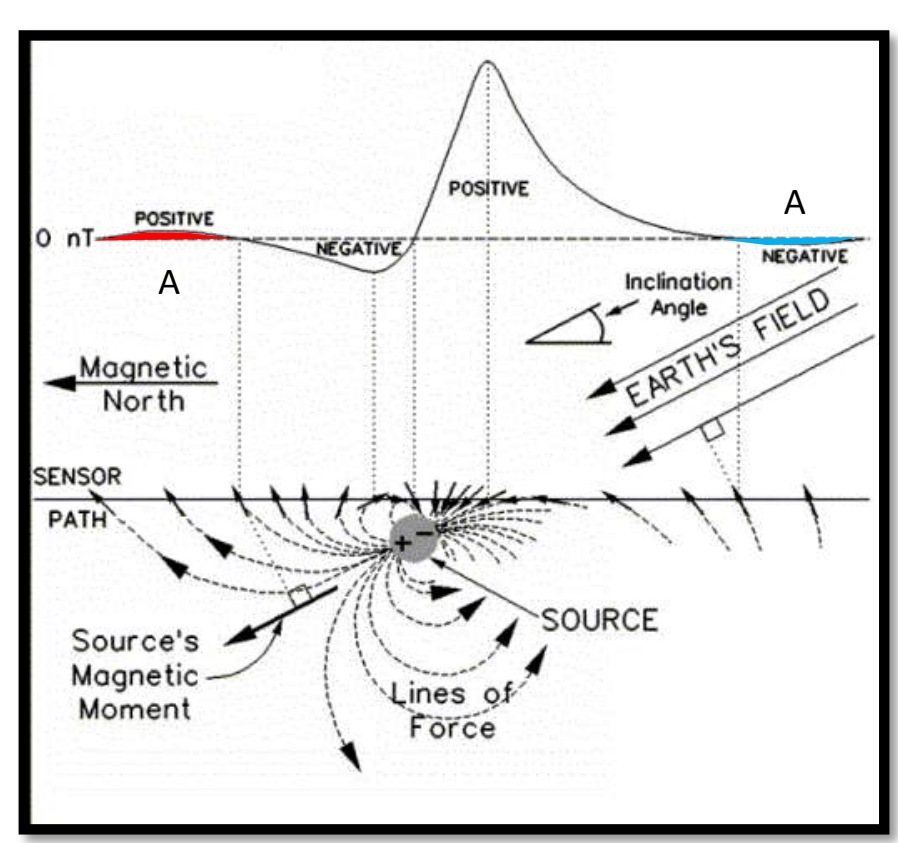

Figure 9: Induced Magnetic Anomaly lower peak amplitude and a smaller magnetic footprint, all other things being equal, than if the same wreck were an intact hull. Unfortunately, the original hull dimensions of 41CL92 are unknown. Although it represents the smallest anomaly known to date for a disarticulated wooden wreck, smaller examples likely exist. A realistic lower limit for the dimensions of a significant anomaly remains open for debate.

The smallest likely size of historic commercial watercraft in the Gulf Coast trade can be determined through research. For example, the average size of wooden sailing vessels registered in the Port of New Orleans during the period $1804-1820$ was $71 \times 21 \mathrm{ft}(21.6 \mathrm{x}$ $6.4 \mathrm{~m}$ ) (based on Works Progress [1941] as summarized in Ford, et al. 2008: 54-71). The smallest vessel registered in New Orleans during the same period was the schooner Tickler, which measured only $29 \times 10 \mathrm{ft}(8.8 \times 3.0 \mathrm{~m})$ (Works Progress Administration 1941: 127), roughly 81 percent the size of the Mag-13 hull.

It seems reasonable, based on comparison with the Mag-13 wreck, that an intact wooden vessel as small as Tickler might have an anomaly measuring as much as 81 percent smaller than the Mag-13 anomaly, that is to say $160 \times 133 \mathrm{ft}(48.8 \times 40.5 \mathrm{~m})$ across, or an average diameter of $147 \mathrm{ft}$. The 41CL92 anomaly, the smallest verified wreck anomaly known to this author, measures 92 percent smaller than the Mag-13 wreck anomaly, possibly because the site is disarticulated. To be conservative, the hypothetical anomaly size for Tickler, likewise, has been adjusted downward by 92 percent, yielding an estimate of $147 \times 122 \mathrm{ft}$ $(44.8 \times 37.2 \mathrm{~m})$, or an average diameter of $135 \mathrm{ft}(41.1 \mathrm{~m})$. This author, therefore, will consider dipoles potentially significant if they align with magnetic north and have a minimum horizontal dimension of at least $135 \mathrm{ft}(41.1 \mathrm{~m})$, which is 81 percent smaller than the 41CL92 anomaly.

\section{Orientation}

Shipwreck anomalies (e.g., Figures 7, 8, 10, and 11) consistently share a common orientation with respect to earth's magnetic field, despite the great diversity of wrecks described above. All wreck anomalies observed by this author, to date, are oriented with their primary negative pole situated north of their positive pole. The local direction of magnetic north agrees, on average, within $+/-10$ degrees of the dipole alignment for 29 verified wreck anomalies, reported in Gearhart (2011b). The maximum reported difference between dipole alignment and magnetic north direction was 26 degrees. A similar orientation 
is expected of all wrecks, as well as all other complex anomaly sources, in mid-latitudes of the northern hemisphere; however, the orientation of anomalies over simple debris sources is not limited.

Shipwrecks, and other complex sources, have anomalies closely aligned to the direction of magnetic north. This phenomenon is believed due to the random orientations of many individual magnetic components that make up each complex source, including shipwrecks. The magnetic field of each component interacts with that of its neighbors. The overlapping portions of fields that oppose one another in direction tend to cancel, while lines of force that run in the same general direction reinforce each other. Since a small portion of each field is aligned with (induced by) earth's local field, the net result of all these interactions is that more reinforcement occurs in the direction of magnetic north than in any other direction, resulting in a north-aligned anomaly. A simple debris source, on the other hand, is a solitary object on the seabed. By definition, there are no nearby sources affecting its magnetic field, thus the alignment of its anomaly is determined not by earth's magnetic field direction but by the object's orientation on the seabed. Hence debris anomalies can be oriented along any point of the compass.

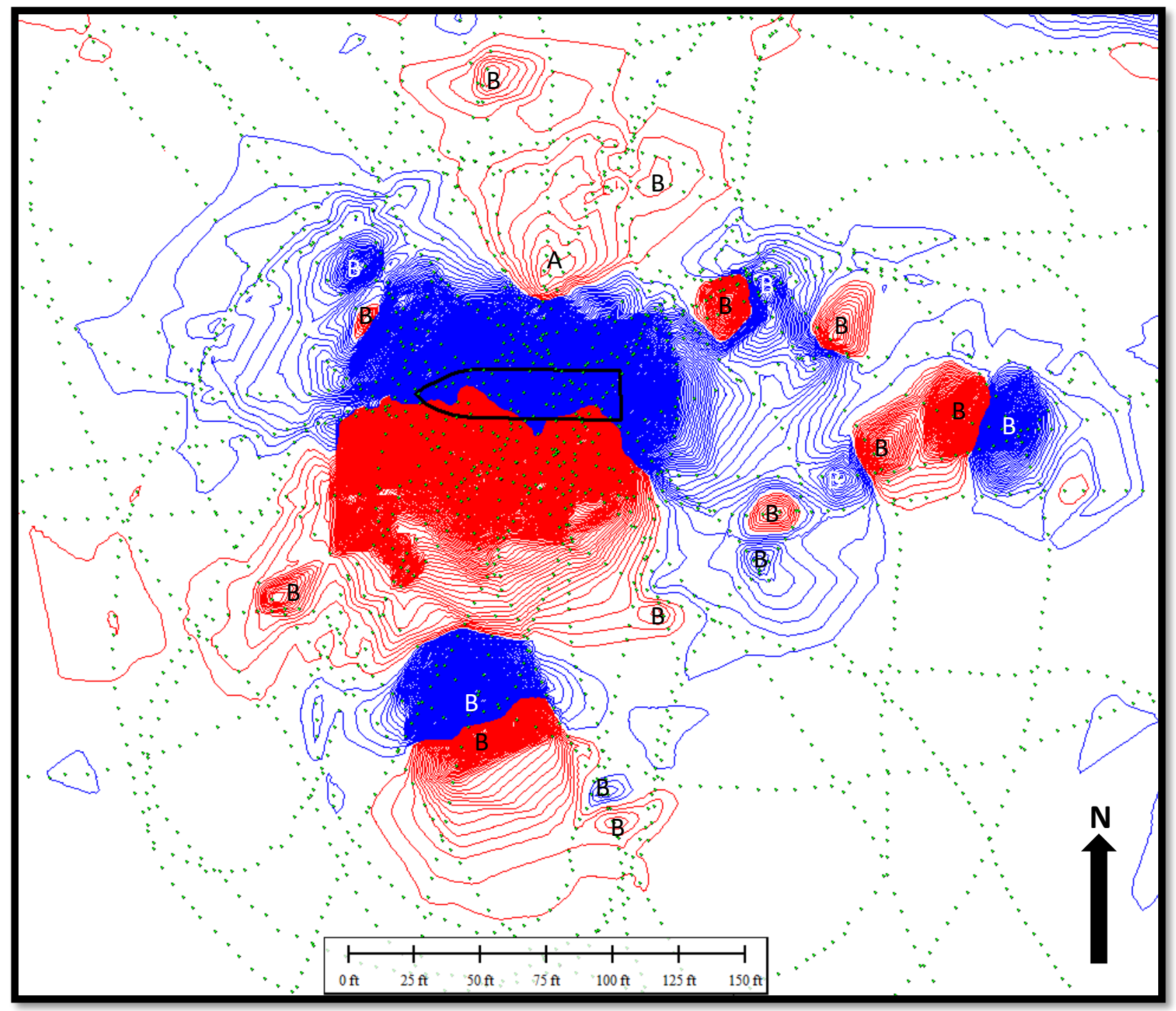

Figure 10: 41CH372 Anomaly (steel hull), 5-nT contour interval 
Orientation can differentiate magnetic anomalies caused by most simple debris sources from anomalies caused by complex sources, including shipwrecks, and has potential to eliminate close to 80 percent of debris anomalies from further archaeological concern. Roughly 20 percent of simple debris sources have northerly orientations like those observed over complex sources. Absent a sonar target, there is no reliable method known, short of physically probing, to differentiate debris having northerly anomaly orientations from complex sources, including potential buried shipwrecks.

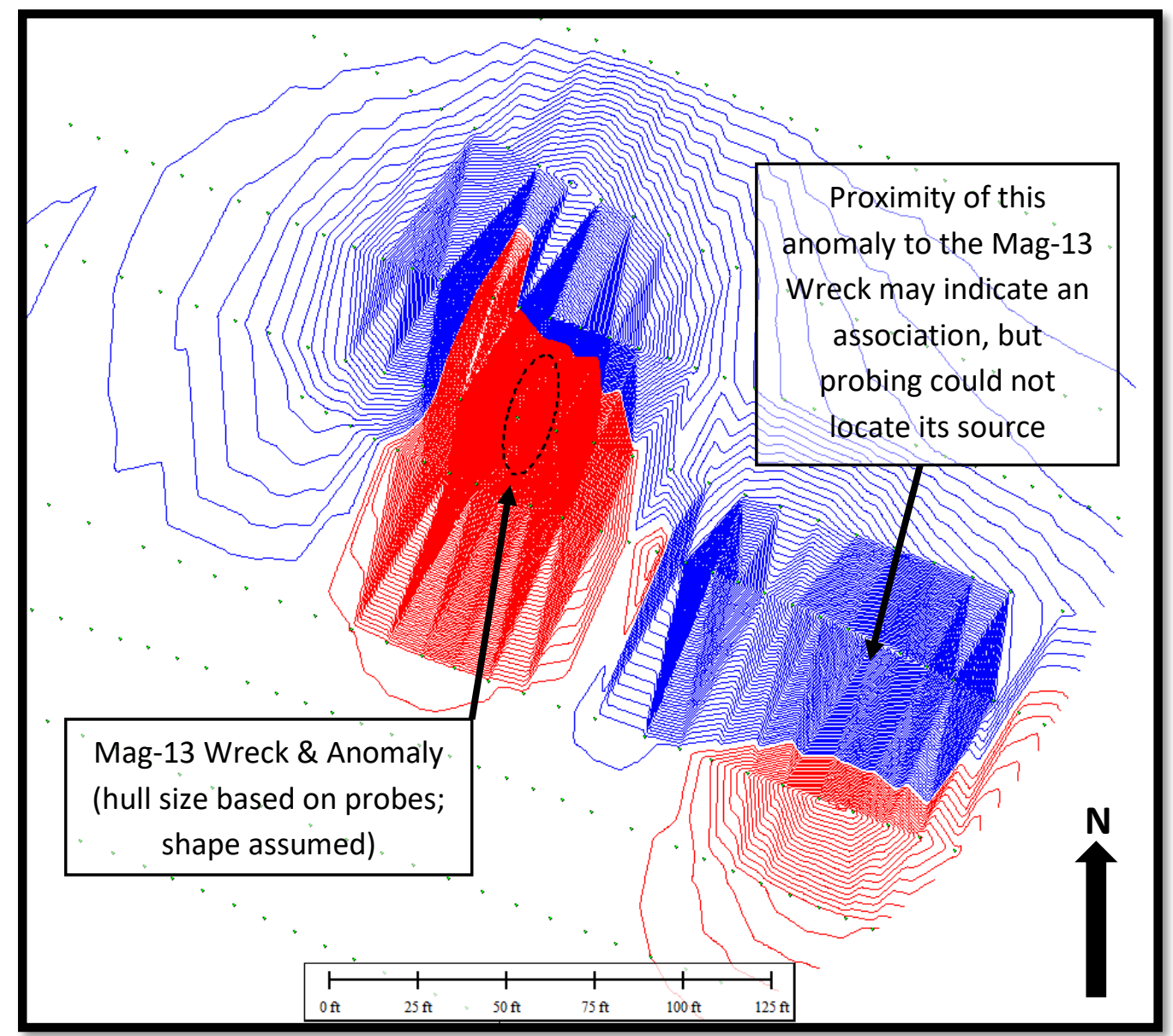

Figure 11: Mag-13 Wreck Anomaly (wooden hull)

5-nT contour interval (Gearhart 2016: 46)

Anomalies can be eliminated from consideration as potential shipwrecks by demonstrating that their orientations differ substantially from the direction of magnetic north. It seems unlikely that a shipwreck could have a magnetic anomaly that is not aligned closely with magnetic north, as this would require a large percentage of the wreck's many ferromagnetic components, by chance, to have the same magnetic moment. On the other hand, the anomaly of a simple debris source should align with earth's magnetic field only when its magnetic moment, as determined by the source's orientation on the seafloor, closely aligns with magnetic north.

The interpretation of magnetic anomalies based on orientation requires comparing unidentified magnetic anomalies, contoured at a 5-nT interval, to the anomaly of a small, verified wreck anomaly, such as 41CL92, shown in Figure 7. One must ensure that the reference anomaly is contoured, oriented and scaled 
using the same parameters as the survey data to which it is compared. Anomalies having a polar orientation similar to that of 41CL92 should be considered possible shipwrecks unless contradicted by other information, such as reliable evidence of an abandoned petroleum well nearby, as anomalies over steel well casings often closely resemble shipwreck anomalies. Information regarding petroleum infrastructure is available on the Texas Railroad Commission's (TxRRC) public, Geographic Information System (GIS) Viewer to rule out association with wells.

\section{Significance Criteria}

BOB's minimum criteria for potential archaeological significance of magnetic anomalies (in mid-latitudes of the northern hemisphere) requires that an anomaly, when surveyed at 20-m intervals, be consistent with the following conditions: a) it must have at least one dipole, oriented with its negative pole north of its positive pole; b) it should be at least $135 \mathrm{ft}$ ( $41.1 \mathrm{~m}$ ) across (to the +/- 5-nT contour); and c) it should appear on a minimum of 2 transects. If survey lines are spaced at 10-m intervals, a significant anomaly should meet all of the above conditions and d) should appear on at least 4 transects. An anomaly's shape usually is not obvious if data is from a single survey transect; thus, additional criteria have been designed to avoid missing significant targets. If survey lines are spaced at 30-m intervals, a significant anomaly e) may be limited to a single transect; and f) may appear as a monopole, provided the transect follows a predominantly east-west heading. Exceptions may be made in either direction, at the Principal Investigator's discretion, based on mitigating circumstances or professional judgment. Resemblance to verified shipwreck anomalies, including the 39 reported by Gearhart (2011b, 2016), should be an important factor in such judgments when close-order survey has been conducted.

\section{Probing Unidentified Anomalies}

Anomalies 1 and 3 were interpreted as potentially significant, based on close-order magnetometer survey results, so probing was recommended to rule out the presence of buried shipwrecks. Antiquities Permit 8926 was amended, in consultation with the State Marine Archaeologist (email exchange between the author and Amy Borgens on August 22, 2019), to include probing investigations. Probing was conducted on both anomalies from August 26-29, 2019. Additional probing was conducted on Anomaly 1 from January 19-21, 2020 to rule out a wreck below the depth achieved by earlier probes.

Probing was performed from a 20 -ft boat by a crew of three persons, including Ed Baxter, Michael Baxter, and the Principal Investigator. Probes were made of iron or PVC pipe connected to a water pump. The boat was navigated to desired locations using Hypack software and a Hemisphere VS131, dual-GPS Heading system (differentially corrected for sub-meter accuracy). Navigation guidance at the helm ensured that the bow of the boat was positioned correctly prior to lowering the probe. A combination of anchors and engine power held the boat stationary as each probe was completed and its position recorded by Hypack.

The proposed horizontal limits of probing at each anomaly were determined in advance based on analysis of magnetic data. Probes were spaced at irregular intervals based on the judgment of the Principal Investigator. A sufficient number of probes were placed across the central portions of selected anomalies to verify the presence/absence of buried shipwrecks. The average maximum spacing between probes was about 10 feet. Probes typically penetrated at least 10 feet below the river bottom, unless an anomaly 
source or refusal layer was discovered at a lesser depth. Deeper probes were completed on Anomaly 1 , in January 2020, to depths exceeding 17 feet below the river bottom, because unconsolidated sediments, interpreted as recent in age, were particularly deep at that location.

\section{Results}

All geophysical data acquired for this project were assessed for their archaeological significance and are illustrated in Appendix A. Magnetic anomalies, greater than $+/-5 \mathrm{nT}$, are illustrated as amplitude contours. Pre-planned survey lines are overlaid by actual survey transects to demonstrate coverage. Side-scan sonar data are illustrated in Appendix A as a composite, mosaic image. Selected anomalies, initially interpreted as significant, are illustrated and described in the text below, and their locations are provided in Appendix B. Results and positions of anomaly probes are tabulated in Appendix C. Appendices A, B and C are redacted from public copies of this report to protect the location of archaeological site 41OR113. Probe depths, without positions, are provided in Appendix D for public use.

Three magnetic anomalies from the initial survey met the minimum archaeological significance criteria, described in Section IV above. Those targets, designated Anomalies 1, 2, and 3, strongly resembled magnetic anomalies observed over verified shipwrecks and initially were recommended for archaeological avoidance. The project sponsor requested additional investigation to determine whether any of those targets was associated with an archaeological site.

BOB requested an amendment of Antiquities Permit 8926 to allow additional investigation of anomalies 1-3. Probing was recommended at anomalies 1 and 3 . A total of 239 probes subsequently were completed (appendices $C$ and D), including 111 probes at Anomaly 1 and 128 probes at Anomaly 3. Probing of Anomaly 2 would have required a separate mobilization involving divers, because this location is significantly deeper than either Anomaly 1 or 3 . Thus, close-order magnetometer survey was recommended at Anomaly 2 in hopes of resolving the question of its significance. Additional investigations resulted in removal of avoidance recommendations from Anomalies 1 and 2. The buried hull of an unidentified, wooden watercraft, measuring $32 \mathrm{ft}$ wide by at least $82 \mathrm{ft}$ long, was discovered in association with Anomaly 3. This wreck has been designated as an archaeological site, 410R113.

Anomaly 1 (Figure 12) has minimum and maximum amplitude of $-725 \mathrm{nT}$ and $+883 \mathrm{nT}$ and measures 215 $\mathrm{ft}$ by $284 \mathrm{ft}$. This anomaly was surveyed at an interval of $10 \mathrm{~m}$, thus the data illustrated in Figure 12 represents a close-order view of the target. The magnetometer sensor was towed $5-11 \mathrm{ft}$ above the sediment at this location. A comparison of Anomaly 1 to the anomaly of Site 41CL92 (upper left image in Figure 12) demonstrates a strong resemblance with verified shipwreck anomalies, thus this target initially was considered significant. The only objects visible in this area on side-scan sonar imagery (Figure 13) are interpreted as tree branches, including one lying flat on the bottom and three projecting vertically from the sediment. One of the vertical objects correlates closely with a large negative anomaly peak; however, given its resemblance to two nearby objects, which are non-magnetic, that correlation might be coincidental. 


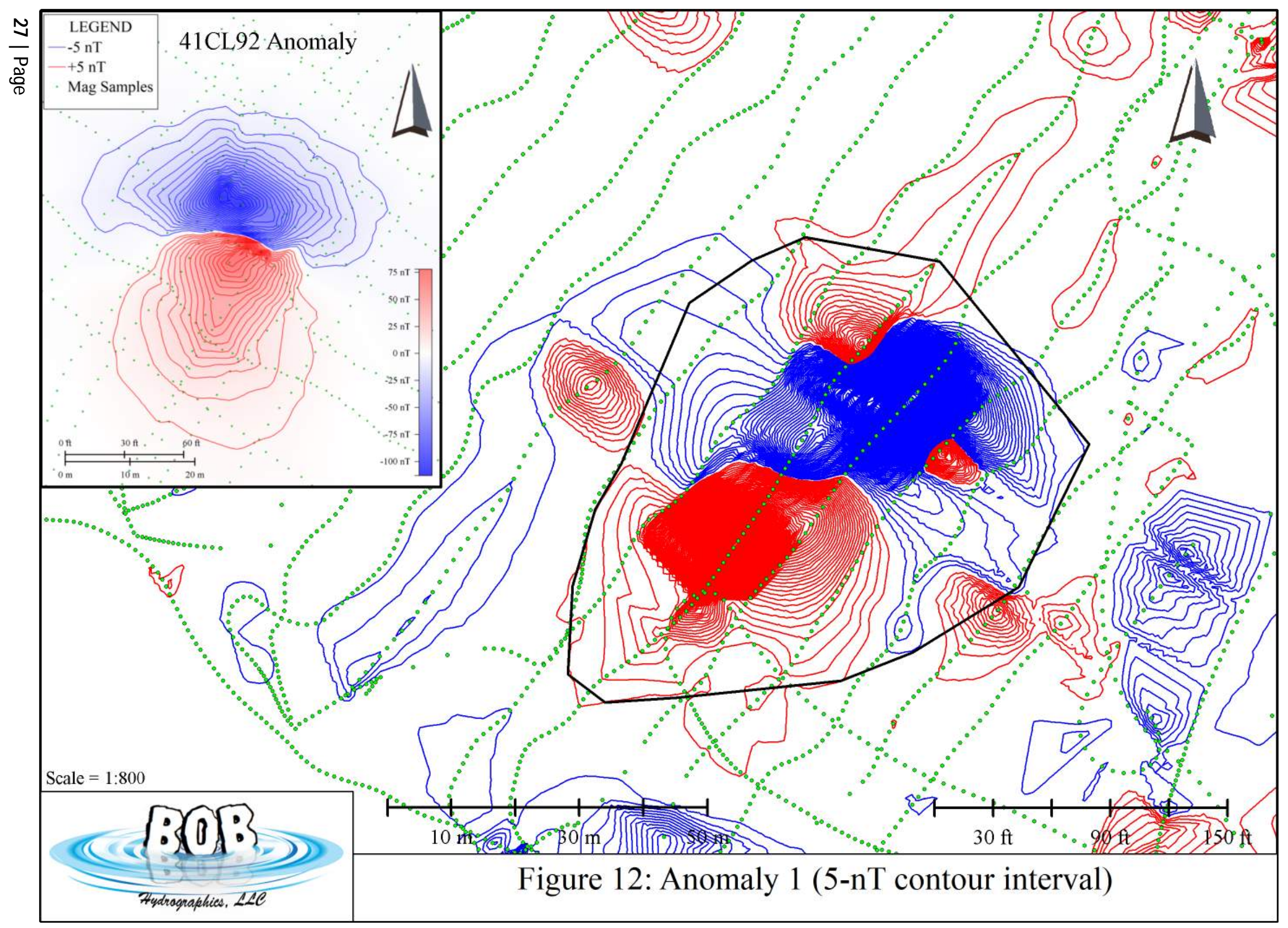




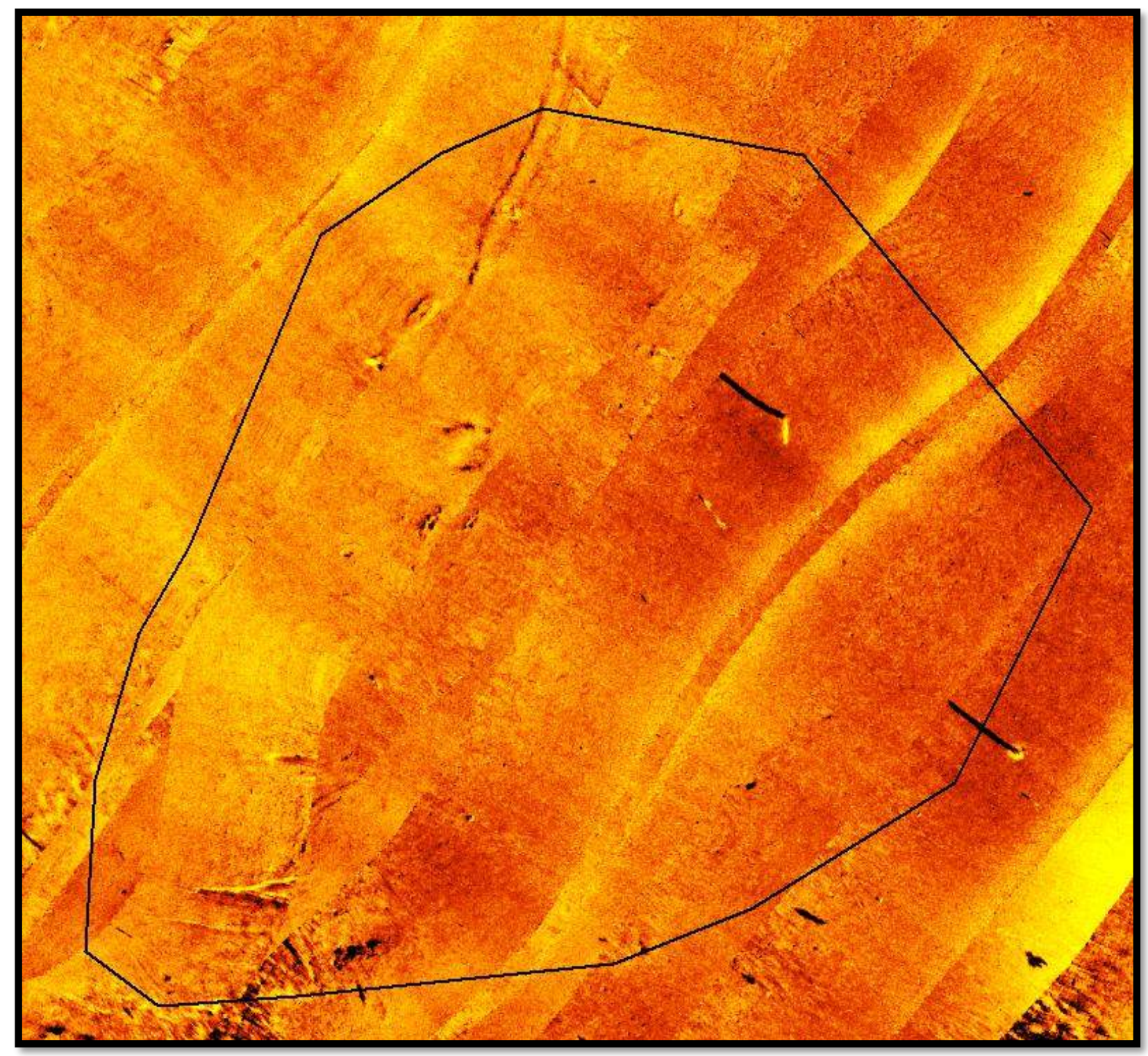

Figure 13: Anomaly 1 Sonar

Results of probing at Anomaly 1 (Figure 14) have conclusively demonstrated that this anomaly is not associated with a buried shipwreck. Average probe penetration was $12.6 \mathrm{ft}$ below the mudline $(21.5 \mathrm{ft}$ below water level). All of the probes at Anomaly 1 encountered very soft, fluid mud in the upper sediment column, which offered almost no resistance to penetration. A probe made of iron pipe typically penetrated at least $10 \mathrm{ft}$ into the river bottom under its own weight (aided by water jetting from its tip). Probes completed in January 2020 achieved greater penetrations, averaging $16.5 \mathrm{ft}$ below the mudline (ranging from 15.1 to $17.8 \mathrm{ft}$ ) to a firm layer of sediment, which is interpreted as the historic river bed. Two of the 111 probes encountered solid objects buried about $8 \mathrm{ft}$ below the river bottom. Locations of those two positive probes, near the inflection point of the magnetic dipole, are highlighted in Figure 14. Their positions with respect to the anomaly suggest a likelihood that this object(s) is the magnetic source of Anomaly 1. 


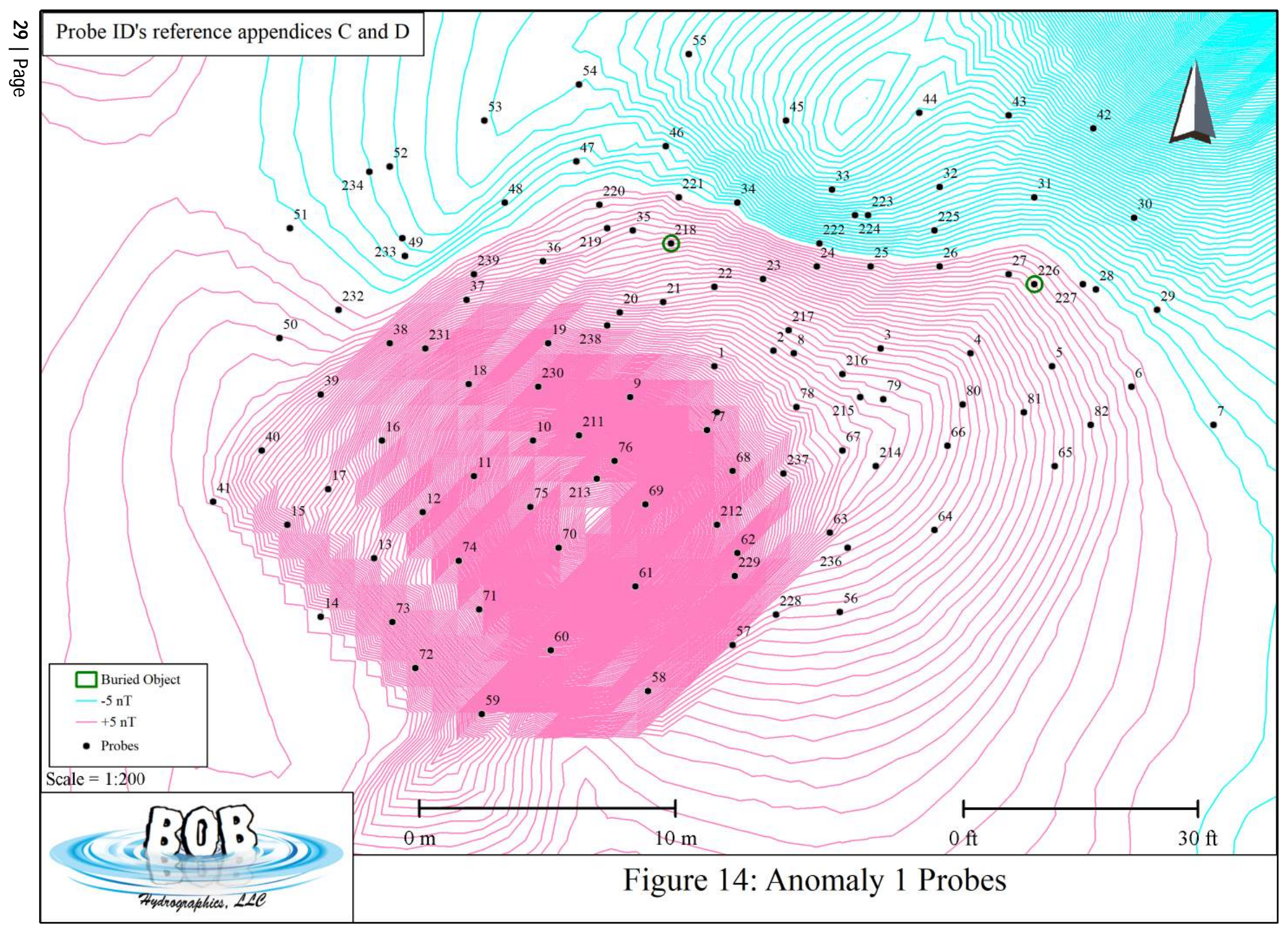


The initial survey over Anomaly 2 (Figure 15) showed minimum and maximum amplitude of -48 nT and +48 nT across an area measuring $195 \mathrm{ft}$ by $256 \mathrm{ft}$. No objects are visible on side-scan sonar imagery over this anomaly (Figure 16), so its source is presumably buried. Anomaly 2 initially had relatively low amplitude but, otherwise, resembled verified wreck anomalies. Low amplitude might have been explained by the distance of the sensor from the anomaly source. The magnetometer was towed $16-20 \mathrm{ft}$ above the sediment at this location, along transects spaced $20 \mathrm{~m}$ apart. However, the source's depth of burial remains unknown and might add substantially to its distance from the sensor if recent sediments are thick at this location.

The source of Anomaly 2 is deep enough that it will not be affected by initial plans for dredging to $-42 \mathrm{ft}$ MLLW; however, it might be impacted by future deepening proposed to $-48 \mathrm{ft} \mathrm{MLLW.} \mathrm{Probing} \mathrm{was} \mathrm{not} \mathrm{the}$ first choice of additional investigations at this location, because its depth would have required the added expense of divers under a separate mobilization. Close-order magnetometer survey was recommended, since it could be accomplished while in the field probing anomalies 1 and 3.

Close-order survey of Anomaly 2 (Figure 17) resolved this target into 5 separate amplitude peaks. The largest dipole has peak amplitude of $-88 \mathrm{nT}$ and $+142 \mathrm{nT}$, well within the range for verified wooden-hulled wrecks. Nevertheless, Anomaly 2 now looks less like a wreck anomaly than it did based on the original survey, and it is no longer recommended for avoidance. The peak amplitude locations are better defined and allow a more precise estimate of the anomaly's orientation with respect to magnetic north. Shipwreck anomalies tend, on average, to align (i.e., the declination of the dipole axis) within +/- 10 degrees of magnetic north. Anomaly 2 has a declination in the range of 29-33 degrees east of magnetic north, which exceeds the maximum 26 degrees observed for a sample of 29 verified wreck anomalies by Gearhart (2011b).

Equally important, is the fact that Anomaly 2 now appears to be contiguous with a linear magnetic pattern extending to the northern shoreline. This pattern suggests that its source might be a linear object, such as a section of pipe or a length of cable. Similar anomalies were observed elsewhere in the project area in association with linear targets on sonar imagery. One possible, or perhaps likely, source for linear anomalies in the survey area might be cables abandoned by the logging industry. It is clear from research discussed in Section III that cut trees were dragged toward this area to create timber rafts prior to 1932 (see Figure 6).

Anomaly 3 (Figure 18) has minimum and maximum amplitude of $-74 \mathrm{nT}$ and $+234 \mathrm{nT}$ and measures $125 \mathrm{ft}$ by $157 \mathrm{ft}$. This anomaly was surveyed at an interval of $10 \mathrm{~m}$, thus the data illustrated in Figure 18 represents a close-order view of the target. The magnetometer sensor was towed 6-11 ft above the sediment at this location. A comparison of Anomaly 3 to the anomaly of Site 41CL92 (upper left image in Figure 18) demonstrates a reasonable resemblance with verified shipwreck anomalies, thus this target was recommended for additional consideration. Parallel, linear targets exposed at the river bottom and visible on sonar (highlighted by white arrows in Figure 19) were originally interpreted as tree branches. These features have been reinterpreted as possible hull timbers based on their correlation with a buried wooden watercraft discovered by probing (area shown in Figure 19). 


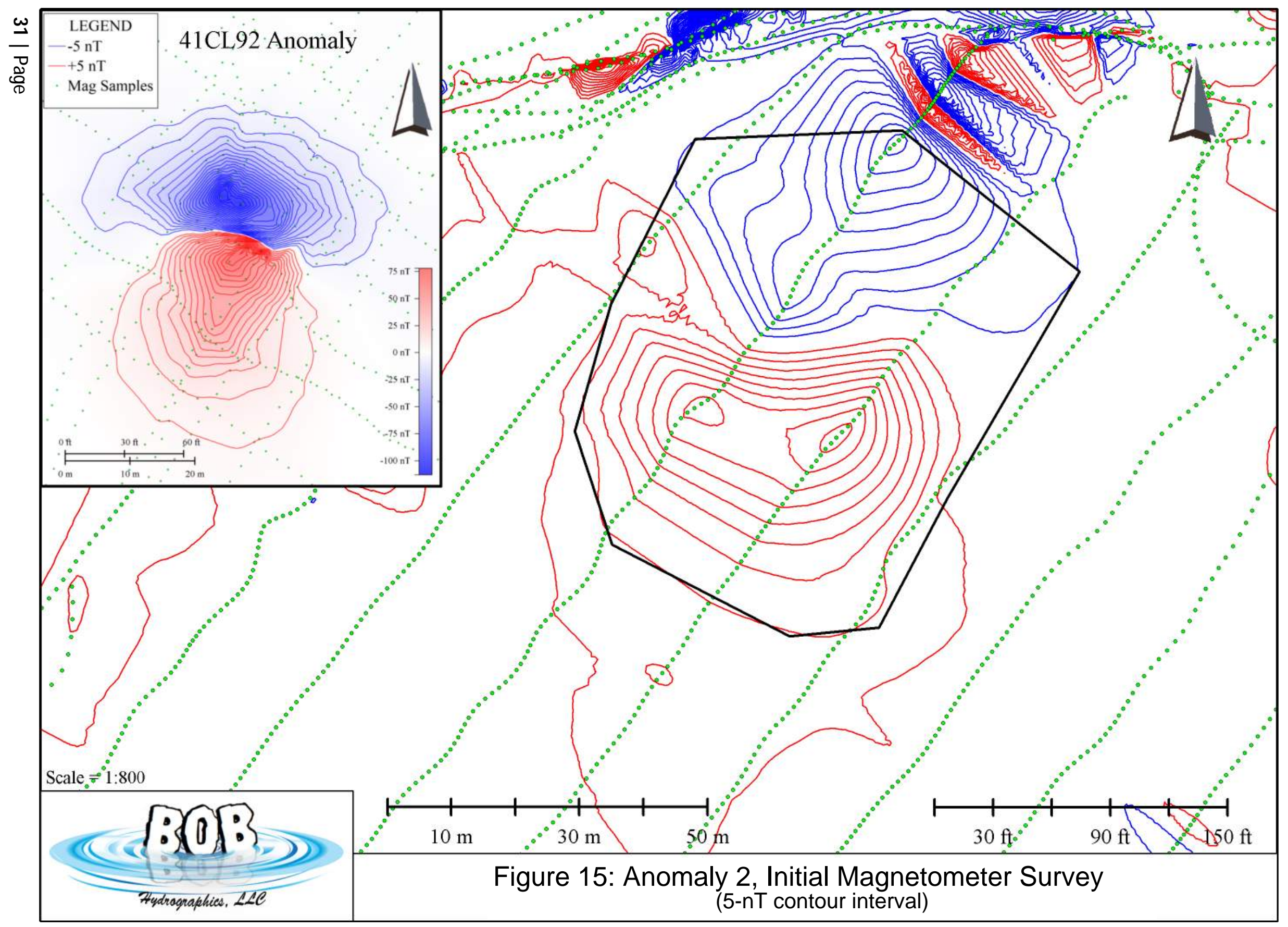




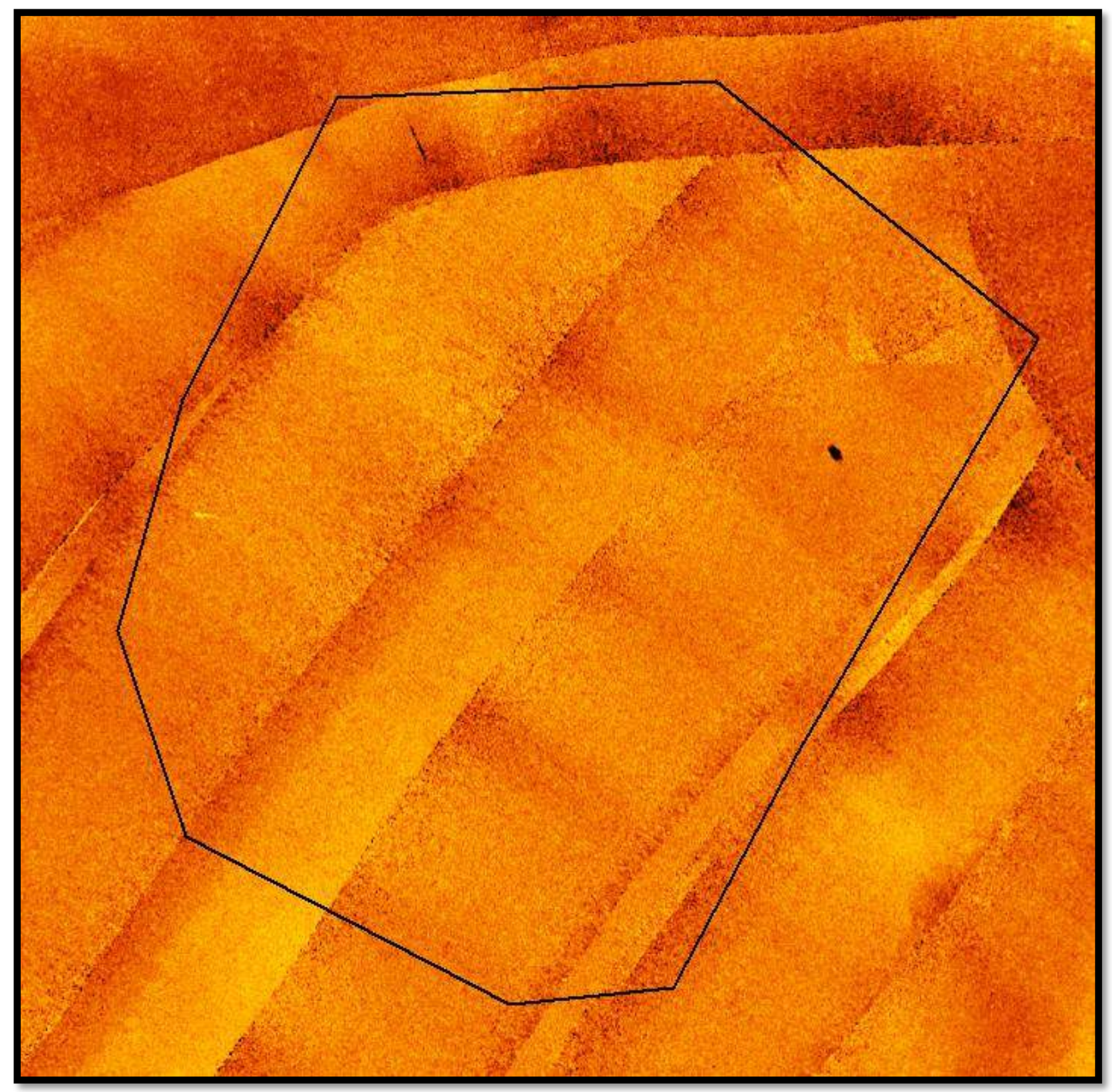

Figure 16: Anomaly 2 Sonar

Results of probing at Anomaly 3 (Figure 20) discovered the buried hull of a wooden watercraft, Site 410R113, measuring $32 \mathrm{ft}$ wide by, at least, $82 \mathrm{ft}$ long. The western end appears to be square, but the shape of the eastern end remains undetermined. Average probe penetration was $10.2 \mathrm{ft}$ below the mudline ( $18.7 \mathrm{ft}$ below water level). The hull appears to have at least $8 \mathrm{ft}$ of vertical relief. The depth of wood burial in probes ranges from $3.2 \mathrm{ft}$ to $11.5 \mathrm{ft}$ below the mudline. The eastern end of wooden structure is believed to be deeper than the probe could reach. Based on the size of Anomaly 3, the hull's full length could be as long as $100 \mathrm{ft}$. The historic significance of this site is unknown and may depend, to some extent, on the type of vessel buried here. For example, this hull might be a purpose-built barge, 


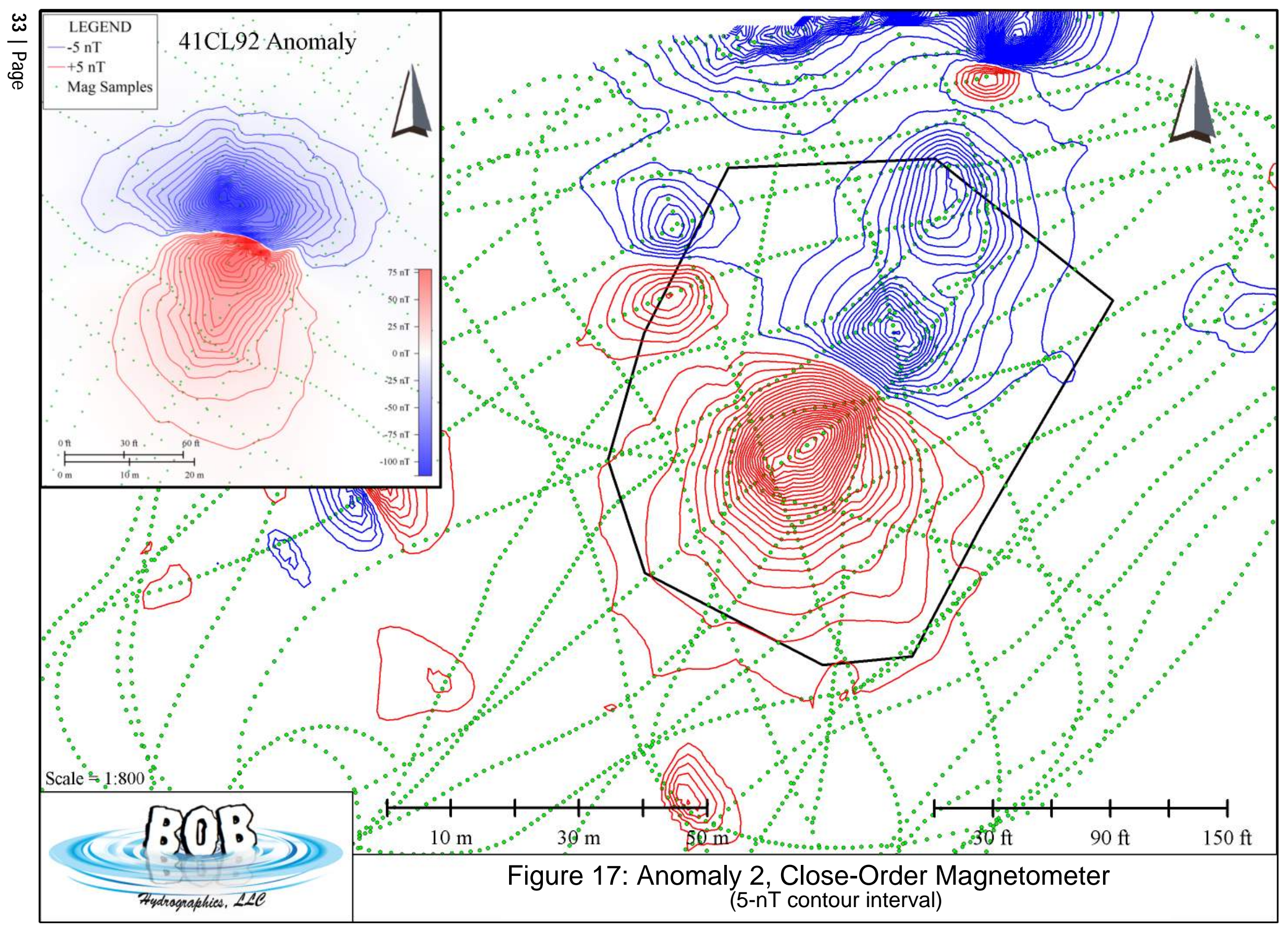




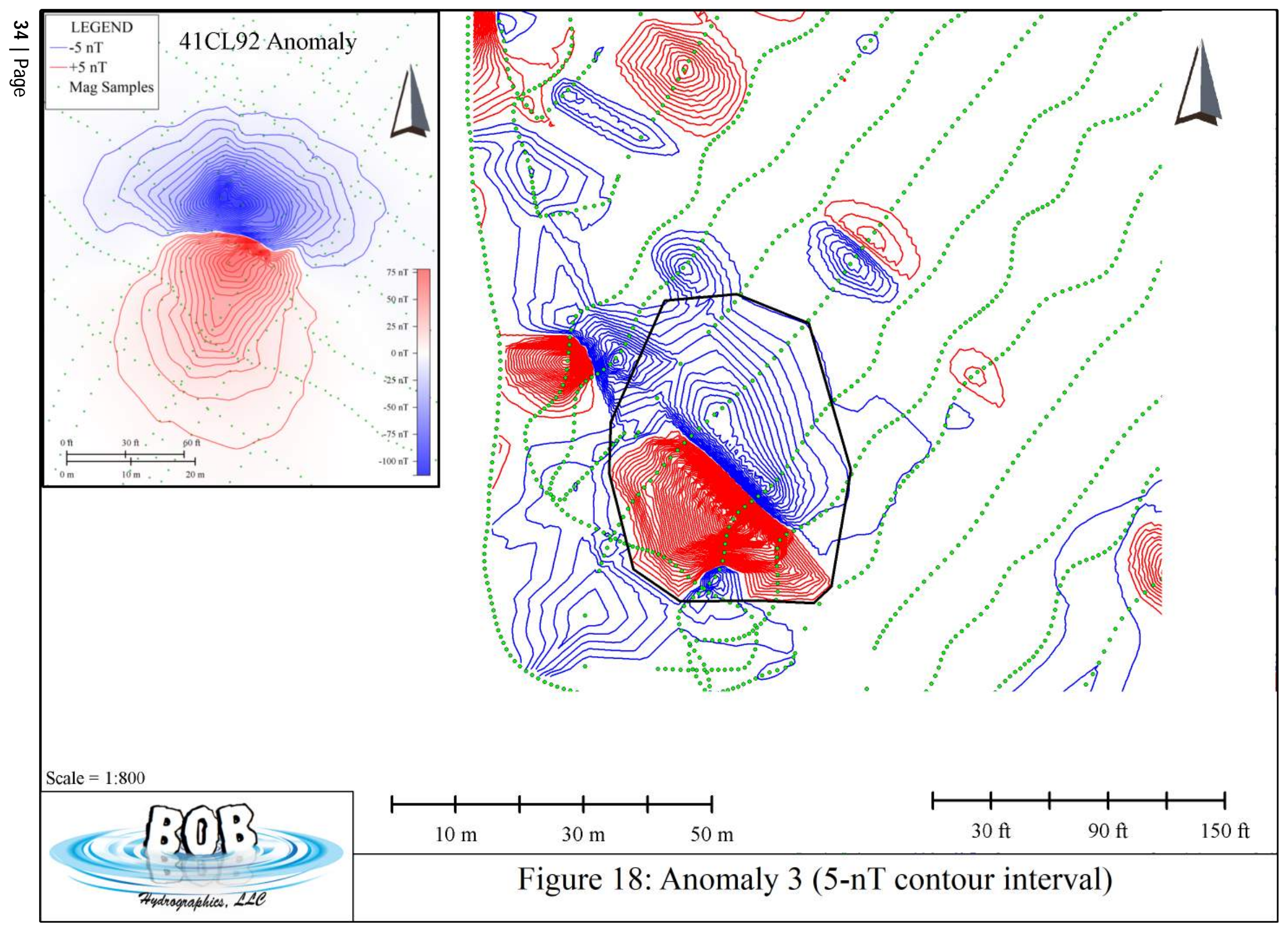




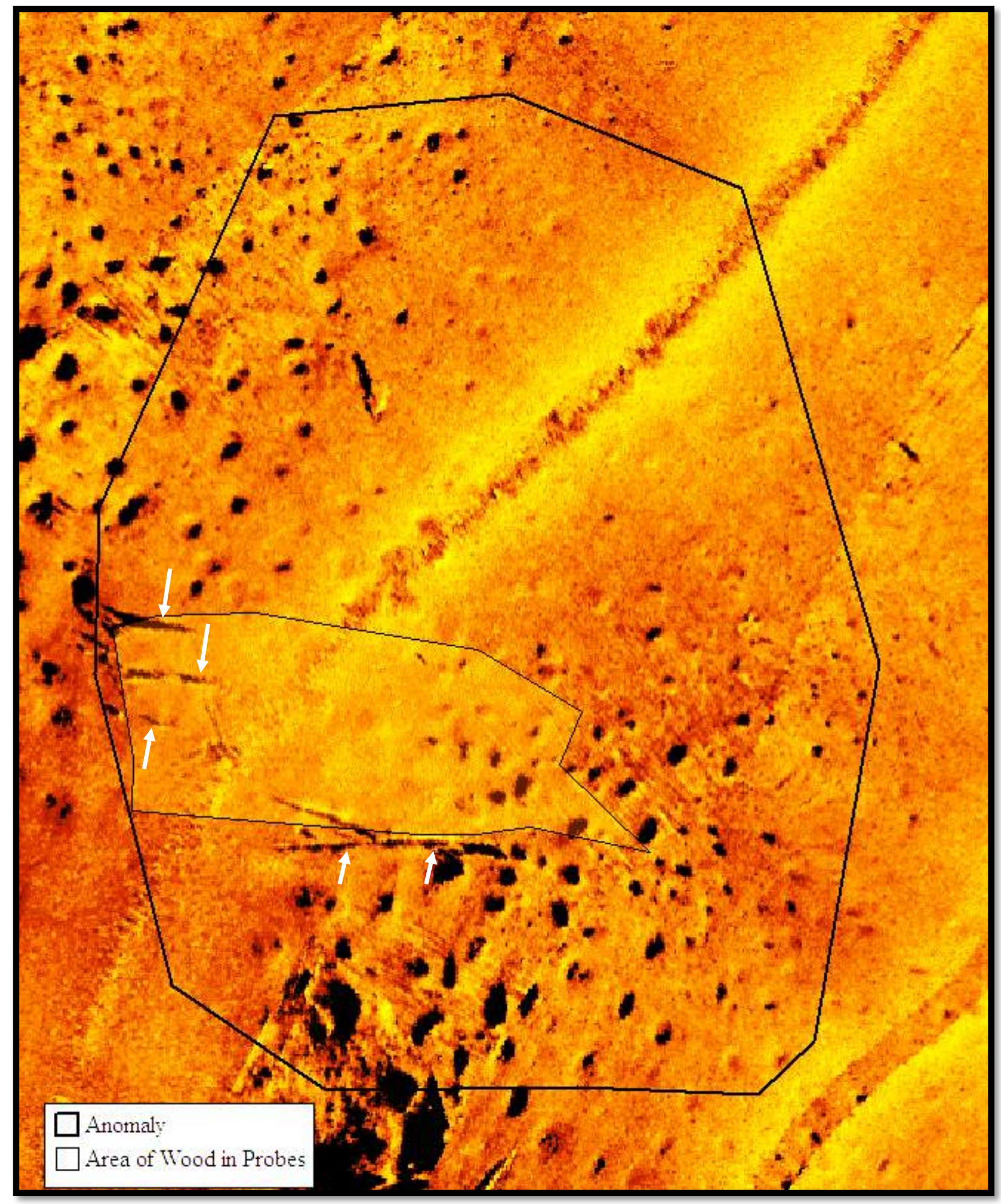

Figure 19: Anomaly 3 Sonar (arrows indicate possible ship timbers) 


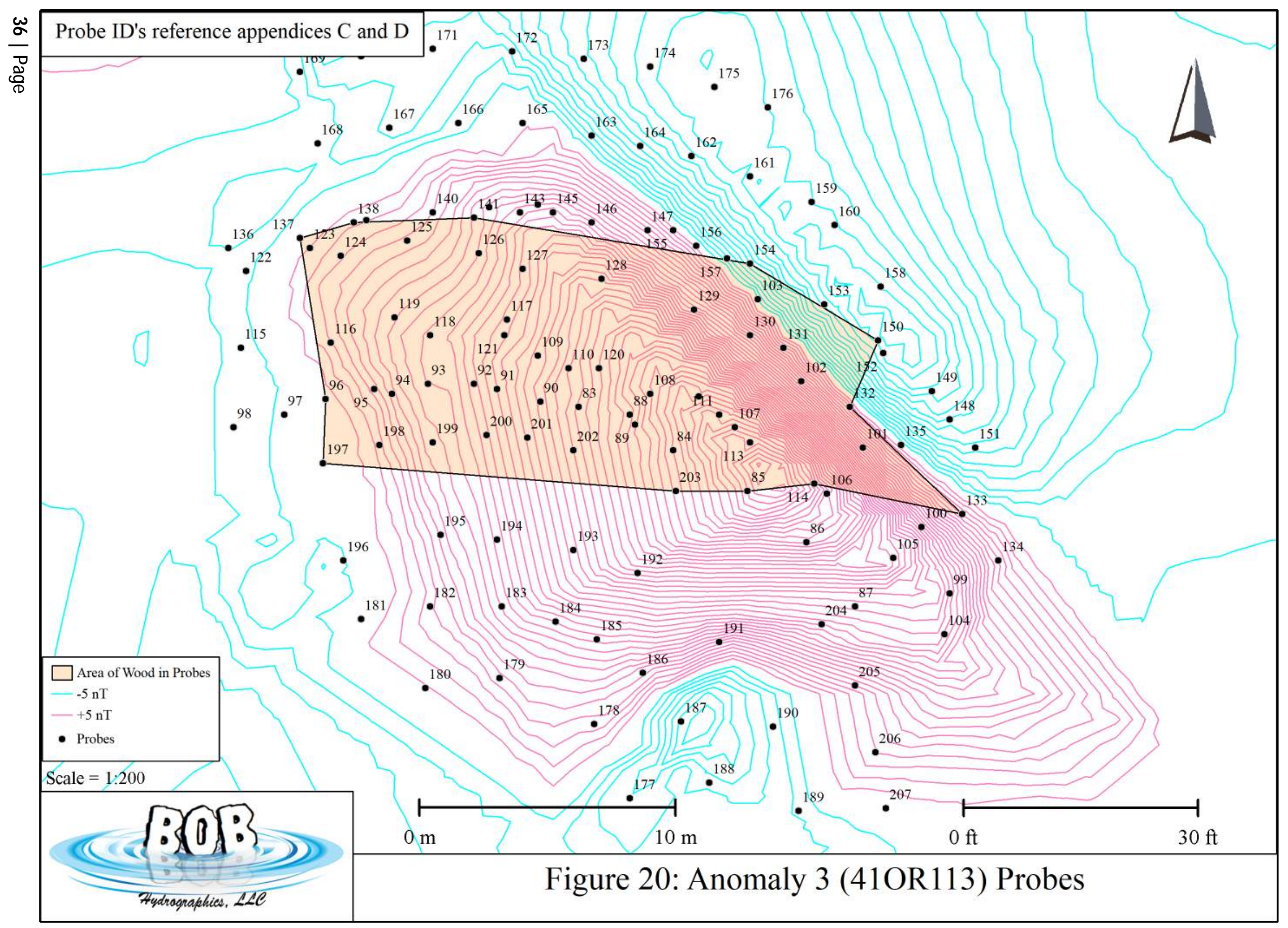


dating from the first half of the 20th century, and similar to many other abandoned examples known along the Texas Coast. Other possibilities include: a sailing ship abandoned here at the end of its useful life; a barge created from the modified hull of a sailing ship; or a steamboat, presumably with machinery removed (based on the low anomaly amplitude).

In addition to the three anomalies considered for their potential archaeological significance, above, the geophysical survey mapped several other features (Appendix A), which may be of general interest to engineers and dredgers. For example, two broad, linear anomalies dominate a substantial area, crossing near the center of the survey in a north-south direction. Side-scan sonar shows what appear to be, at least, 3 parallel pipes or large-diameter cables, intermittently exposed and coincident with the alignment of these anomalies (Appendix A). The TxRRC GIS database does not indicate pipes crossing this area; although, it's possible that some were installed prior to the period of their records. Approximate exposures of linear sonar features, presumed to be pipes, are delineated by linework overlaid on magnetic anomalies in Appendix A. These features measure less than $1 \mathrm{ft}$ across, but they occur over an area greater than $1,000 \mathrm{ft}$ long. They are not of cultural concern but presumably would interfere with dredging.

Records from the TXRRC GIS database indicate that several petroleum wells have been drilled from surface locations near the survey area. Evidence suggests that some wells have been incorrectly plotted by TxRRC; therefore, only wells associated with geophysical targets are included in Appendix A to avoid confusion. The TxRRC plots the surface locations of three wells (3ST, S4ST, and 5) in the survey area, which seems unlikely given the added cost of drilling from a floating platform. A surveyor's sketch, filed with the TxRRC, indicates that the two producing wells (3ST and S4ST) actually were drilled from Smith Island southeast of the survey area. The third well (No. 5) was a dry hole. No records could be found to clarify its location; however, there is no anomaly in the survey area that definitively correlates with the TxRRC charted position of Well 5.

Two plugged wells, 3ST and S10 (American Petroleum Institute wells 361-00071 and 361-00085, respectively), may account for magnetic anomalies on the margins of the survey area (Appendix $A)$. Well 3ST was drilled by Bering Operating Co. in 1972, was re-drilled to sidetrack a collapsed casing by The George R. Brown Partnership in 1992, and was plugged in 2002. Well S10 was drilled by The George R. Brown Partnership in 1962 and was plugged in 2002. Steel casing remains in both wells for their full depth below their upper cement plugs.

\section{Recommendations}

One geophysical target, Anomaly 3, has been definitively associated with a buried, wooden watercraft, designated Site 41OR113. This site is potentially eligible as a State Archaeological Landmark and for listing on the National Register of Historic Places. Archaeological avoidance of $410 R 113$ is recommended. Bottom-disturbing activities must be avoided for at least $50 \mathrm{~m}$ beyond the limits of wreckage. If Site $410 R 113$ cannot be successfully avoided, then further investigation would be required to determine whether the site is historically significant and potentially eligible for the National Register of Historic Places. 
All disturbance of submerged lands must be avoided within state-mandated target and survey avoidance buffers. Avoidance buffers are $50 \mathrm{~m}$ wide for inland waters. Disturbances include, but are not limited to, dredging, trenching, anchoring, use of barge spuds, and pile driving. Areas located outside of designated archaeology avoidance zones are recommended for cultural resource clearance. If shipwreck remains, or other potentially historic or archaeological materials, are discovered during construction, work must be halted immediately within $50 \mathrm{~m}$ (164 ft) of the find, and steps taken to ensure that the site is not disturbed. Promptly notify the State Marine Archaeologist at the THC for further direction concerning the discovery. 


\section{References Cited}

Alperin, Lynn M. 1977. Custodians of the Coast: History of the United States Army Engineers at Galveston. Galveston District, U.S. Army Corps of Engineers, Galveston, Texas.

Block, W.T. 1976. A History of Jefferson County, Texas, from Wilderness to Reconstruction. Master's thesis, Lamar University. Nederland Publishing Company, Nederland, Texas.

Borgens, Amy. 2004. Analysis of the Pass Cavallo Wreck Assemblage, Matagorda Bay, Texas. Master's thesis, Texas A\&M University, College Station.

Bolton, Herbert Eugene. 1915. Texas in the Middle Eighteenth Century: Studies in Spanish Colonial History and Administration. University of California Publications in History, Volume III. University of California Press, Berkeley.

Cabeza de Vaca, Álvar Núñez. 2013. Chronicle of the Narváez Expedition, Translation of 'La Relacion', translated by David Frye, edited by Ilan Stavans. Norton Critical Edition.

Chipman, Donald E., and Harriett Denise Joseph. 2010. Spanish Texas 1519-1821, Revised Edition. University of Texas Press, Austin.

De Cordova, Jacob. 1858. Texas: Her Resources and Her Public Men. J.B. Lippincott \& Co., Philadelphia.

Enright, Jeffrey and Robert Gearhart. 2005. Historic properties identification, oyster reef identification, and pipeline and obstruction identification for the Sabine/Neches Waterway Widening and Deepening, Jefferson and Orange counties, Texas and Cameron Parish, Louisiana. Prepared for the U.S. Army Corps of Engineers, Galveston District. PBS\&J Document 040264. Austin, Texas.

Ford, B., A. Borgens, W. Bryant, D. Marshall, P. Hitchcock, C. Arias and D. Hamilton. 2008. Archaeological excavation of the Mardi Gras Shipwreck (16GM01), Gulf of Mexico Continental Slope. OCS Report MMS 2008-037. U.S. Department of Interior, Minerals Management Service, Gulf of Mexico OCS Region, New Orleans.

Foster, Eugene, Ty Summerville, and Thomas Brown. 2006. The Texas Historic Overlay: A Geographic Information System of Historic Map Images for Planning Transportation Projects in Texas. PBS\&J Document 060206. Texas Department of Transportation, Environmental Affairs Division, Austin.

Garrison, E. G., C. P. Giammona, F. J. Kelly, A. R. Tripp and G. A. Wolff. 1989. Historic shipwrecks and magnetic anomalies of the northern Gulf of Mexico: Reevaluation of archaeological resource management zone 1. Volume II: technical narrative. OCS Study, MMS 89-0024. U.S. Department of the Interior, Minerals Management Service, Gulf of Mexico OCS Region.

Gearhart, Robert. 2011a. Wooden Shipwrecks of the Central and Western Gulf of Mexico. Paper presented at Offshore Technology Conference, Houston, Texas.

Gearhart, Robert. 2011b. Archaeological Interpretation of Marine Magnetic Data, Chapter 4 in The Oxford Handbook of Maritime Archaeology, Alexis Catsambis, Ben Ford, and Donny L. Hamilton, editors, pp. 90113. Oxford University Press, New York, New York. 
Gearhart, Robert. 2016. Marine Archaeological Survey of Proposed North Jetty Sand Search, Galveston County, Texas. Prepared for HDR Engineering, Inc. Surveying And Mapping, LLC, Austin, Texas.

Gearhart, Robert. 2019. Marine Archaeology Assessment, Sabine-Neches Waterway Channel Improvement Project, Jefferson and Orange Counties, Texas and Cameron Parish, Louisiana. Prepared for Perennial Environmental Services, LLC by BOB Hydrographics, LLC, Cedar Park, Texas.

Gearhart, Robert, John Neville, and Steven Hoyt. 1990. California, Oregon, and Washington Archaeological Resource Study, Volume IV: History. Prepared for Minerals Management Services, Pacific Region. OCS Study MMS 90-0090. Espey, Huston \& Associates, Inc., Austin, Texas.

Hackett, C.W. 1931. Pichardo's treatise on the limits of Texas and Louisiana. The University of Texas Press, Austin.

Hamilton, Donny. 2010. Methods of Conserving Archaeological Material from Underwater Sites, Revision No. 2. Conservation Files: ANTH 605, Conservation of Cultural Resources I. Nautical Archaeology Program, Texas A\&M University, http://nautarch.tamu.edu/CRL/conservationmanual/, last accessed on 27 May 2019.

Hoffman, Paul E. 1996. A History of Louisiana before 1813. Louisiana State University Bookstore, Baton Rouge.

Hoskins, Sara, Amy Borgens, and Jenna Enright. 2007. Eligibility testing of the unknown shipwreck (410R90) adjacent to Interstate Highway 10 at the Neches River Bridge, Orange County, Texas. Prepared for the Texas Department of Transportation. PBS\&J Document 070119. Austin, Texas.

Hoyt, Steven and James Schmidt. 1997. Diving Assessments for Twenty-six Localities, Sabine Pass Channel, Jefferson County, Texas, Cameron Parish, Louisiana. Prepared for the U.S. Army Corps of Engineers, Galveston District. EH\&A Document No. 960983. Austin, Texas.

Hoyt, Steven, James Schmidt, and Robert Gearhart. 1994. Magnetometer Survey of Sabine Pass Channel and Assessment of the Clifton, 41JF65, Jefferson County, Texas, Cameron Parish, Louisiana. Prepared for the U.S. Army Corps of Engineers, Galveston District. EH\&A Document 940510, Austin, Texas.

Jackson, V.G. 1930. A history of Sabine Pass. Unpublished Master's thesis. The University of Texas.

Jefferson County Historical Commission. 2018. A History of Jefferson County, Texas. https://www.co.jefferson.tx.us/Historical Commission/pdfjs/web/viewer.html?file=files/History/Jeffers on County History 2015-12-03.pdf, last accessed on 21 August 2018.

Linden, Sarah and Charles Pearson. 2014. Phase I Marine Cultural Resources Remote-Sensing Survey in Buffalo Bayou for the Proposed Kinder Morgan Export Terminal, Pasadena, Harris County, Texas. Coastal Environments, Inc. Corpus Christi, Texas.

Lidgerwood Manufacturing Company. 1905. Logging by Steam. Published by The Logging Machinery Department of the Lidgerwood Manufacturing Company, New York, New York.

Lugo-Fernandez, A., D.A. Ball, M. Gravois, C. Horrell, and J.B. Irion. 2007. Analysis of the Gulf of Mexico's Veracruz-Havanna Route of La Flota de la Nueva España. Journal of Maritime Archeology (2007) 2:24-47. 
Mason, Alan S. 2019. Orange County, in Handbook of Texas Online, accessed July 11, 2019, http://www.tshaonline.org/handbook/online/articles/hco03. Uploaded on June 15, 2010. Modified on April 30, 2019. Published by the Texas State Historical Association.

McCaslin, Richard B., Donald E. Chipman, and Andrew J. Torget, editors. 2013. This Corner of Canaan: Essays on Texas in Honor of Randolph B. Campbell. University of North Texas Press, Denton.

McDonald, David, and J. Barto Arnold III. 1979. Documentary Sources for the Wreck of the New Spain Fleet of 1554. Texas Antiquities Committee, Publication \#8. Austin.

Pearson, Charles E. 2010. Results of a Cultural Resources, Remote-Sensing Survey in Star Bayou, Orange County, Texas. Prepared for E. Arnaud by Coastal Environments, Inc. Baton Rouge, Louisiana.

Pearson, Charles E. and Paul E. Hoffman. 1995. The Last Voyage of El Nuevo Constante: The Wreck and Recovery of an Eighteenth-Century Spanish Ship Off the Louisiana Coast. Louisiana State University Press, Baton Rouge.

Teal, Arlia A. 1973. They Called Us River Hogs. Oral interview by Nina Harden, Opportunity Valley News, August 29. Reprinted in Las Sabinas XV(4): 23-35, October 1989.

United States Army Corps of Engineers. 1911. Tactical Map, Beaumont Quadrangle, Grid Zone D. Engineer Reproduction Plant, U.S, Army, Washington Barracks, D.C.

United States Coast and Geodetic Survey. 1926. Chart 533, Sabine and Neches Rivers. Washington, D.C. Courtesy of Texas General Land Office.

United States Geological Survey. 1932. Beaumont Quadrangle, 1932 edition.

United States Department of the Treasury. 1906-1946. Annual List of Merchant Vessels of the United States. U.S. Government Printing Office, Washington, D.C.

United States House of Representatives. 1882. Survey of Sabine Pass, Texas. Letter from The Secretary of War, transmitting A report of the Chief of Engineers of the results of the survey of the entrance to Sabine Pass, Texas. Executive Documents of the House of Representatives for the First Session of the FortySeventh Congress, 1881-1882, Volume 22, Document 147. Government Printing Office, Washington.

Von Rosenberg, W., Captain. 1863. Topographical Map of the Country Between Sabine and Neches Rivers and North of the Texas and New Orleans Railroad in the State of Texas and Adjoining Part of Louisiana. Image courtesy of the National Archives, Washington, D.C.

Weddle, Robert S. 1991. The French Thorn: Rival Explorers in the Spanish Sea, 1682-1762. Texas A\&M University Press, College Station, Texas.

Weddle, Robert S. 1995. Changing Tides: Twilight and Dawn in the Spanish Sea, 1763-1803. Texas A\&M University Press, College Station, Texas.

Weddle, Robert S. 2001. The Wreck of the Belle, the Ruin of La Salle. The Texas Historical Commission.

Works Progress Administration. 1941. Ship Registers and Enrollments of New Orleans, Louisiana, Volume I (1804-1820). Prepared by the Survey of Federal Archives in Louisiana, Division of Community Service Programs. T.S. Hill Memorial Library, Louisiana State University, Baton Rouge. 
Appendix A: Geophysical Survey Results (Not for Public Disclosure)

A-1 | P a g e 
Appendix B: Summary of Significant Findings (Not for Public Disclosure) 
Appendix C: Probing Results and Positions (Not for Public Disclosure) 
Appendix D: Probing Results

\begin{tabular}{|c|c|c|}
\hline $\begin{array}{l}\text { Probe } \\
\text { ID }\end{array}$ & Notes (depths are ft below river bottom) & $\begin{array}{l}\text { Est. River Bottom } \\
\text { Penetration (ft) }\end{array}$ \\
\hline 1 & soft mud & 8.9 \\
\hline 2 & soft mud & 10.8 \\
\hline 3 & soft mud & 10.8 \\
\hline 4 & soft mud & 10.7 \\
\hline 5 & soft mud & 10.7 \\
\hline 6 & soft mud & 10.6 \\
\hline 7 & soft mud & 11.6 \\
\hline 8 & soft mud & 11.8 \\
\hline 9 & soft mud & 12 \\
\hline 10 & soft mud & 11.4 \\
\hline 11 & soft mud & 11.7 \\
\hline 12 & soft mud & 12 \\
\hline 13 & soft mud & 12.3 \\
\hline 14 & soft mud & 12.5 \\
\hline 15 & soft mud & 11.4 \\
\hline 16 & soft mud & 11.9 \\
\hline 17 & soft mud & 12.2 \\
\hline 18 & soft mud & 11.4 \\
\hline 19 & soft mud & 11.1 \\
\hline 20 & soft mud & 10.9 \\
\hline 21 & soft mud & 10.8 \\
\hline 22 & soft mud & 10.8 \\
\hline 23 & soft mud & 10.7 \\
\hline 24 & soft mud & 10.6 \\
\hline 25 & soft mud & 11.6 \\
\hline 26 & soft mud & 11.5 \\
\hline 27 & soft mud & 10.5 \\
\hline 28 & soft mud & 10.4 \\
\hline 29 & soft mud & 10.3 \\
\hline 30 & soft mud & 11 \\
\hline 31 & soft mud & 11.2 \\
\hline 32 & soft mud & 11.4 \\
\hline 33 & soft mud & 11.5 \\
\hline 34 & soft mud & 11.6 \\
\hline 35 & soft mud & 11.8 \\
\hline 36 & soft mud & 12 \\
\hline 37 & soft mud & 11.2 \\
\hline
\end{tabular}




\begin{tabular}{|c|c|c|}
\hline $\begin{array}{l}\text { Probe } \\
\text { ID }\end{array}$ & Notes (depths are ft below river bottom) & $\begin{array}{l}\text { Est. River Bottom } \\
\text { Penetration (ft) }\end{array}$ \\
\hline 38 & soft mud & 11.5 \\
\hline 39 & soft mud & 11.8 \\
\hline 40 & soft mud & 12.3 \\
\hline 41 & soft mud & 12.5 \\
\hline 42 & soft mud & 10.8 \\
\hline 43 & soft mud & 11.1 \\
\hline 44 & soft mud & 11.3 \\
\hline 45 & soft mud & 11.4 \\
\hline 46 & soft mud & 11.6 \\
\hline 47 & soft mud & 11.8 \\
\hline 48 & soft mud & 10.9 \\
\hline 49 & soft mud & 11.2 \\
\hline 50 & soft mud & 11.8 \\
\hline 51 & soft mud & 11.8 \\
\hline 52 & soft mud & 11.3 \\
\hline 53 & soft mud & 11.9 \\
\hline 54 & soft mud & 11.7 \\
\hline 55 & soft mud & 11.5 \\
\hline 56 & soft mud & 11.9 \\
\hline 57 & soft mud & 12.2 \\
\hline 58 & soft mud & 12.4 \\
\hline 59 & soft mud & 12.7 \\
\hline 60 & soft mud & 12.2 \\
\hline 61 & soft mud & 11.9 \\
\hline 62 & soft mud & 11.8 \\
\hline 63 & soft mud & 12.6 \\
\hline 64 & soft mud & 12.4 \\
\hline 65 & soft mud & 12 \\
\hline 66 & soft mud & 12 \\
\hline 67 & soft mud & 12.2 \\
\hline 68 & soft mud & 11.3 \\
\hline 69 & soft mud & 11.5 \\
\hline 70 & soft mud & 11.7 \\
\hline 71 & soft mud & 12.3 \\
\hline 72 & soft mud; firmer at bottom & 12.4 \\
\hline 73 & soft mud & 11.4 \\
\hline 74 & soft mud & 12.1 \\
\hline 75 & soft mud & 11.6 \\
\hline 76 & soft mud & 11.3 \\
\hline
\end{tabular}




\begin{tabular}{|c|c|c|}
\hline $\begin{array}{l}\text { Probe } \\
\text { ID }\end{array}$ & Notes (depths are ft below river bottom) & $\begin{array}{l}\text { Est. River Bottom } \\
\text { Penetration (ft) }\end{array}$ \\
\hline 77 & soft mud & 11.1 \\
\hline 78 & soft mud & 11.1 \\
\hline 79 & soft mud & 12 \\
\hline 80 & soft mud & 11.9 \\
\hline 81 & soft mud & 11.9 \\
\hline 82 & soft mud & 11.8 \\
\hline 83 & hard wood & 7.9 \\
\hline 84 & hard wood & 8.7 \\
\hline 85 & gravelly; then hard & 6.9 \\
\hline 86 & mud & 11.1 \\
\hline 87 & firm layer at river bottom; then soft & 11.2 \\
\hline 88 & wood; solid but sticky & 9.8 \\
\hline 89 & firm sediment layer at $3.2 \mathrm{ft}$; wood at full depth & 9.7 \\
\hline 90 & gravelly at $5.4 \mathrm{ft}$; sticky wood at depth & 8.9 \\
\hline 91 & gravel at $3.9 \mathrm{ft}$; could not break through & 3.9 \\
\hline 92 & $\begin{array}{l}\text { sticky wood at } 3.1 \mathrm{ft} \text {; moved } 3 \mathrm{ft} \text { north and } \\
\text { found gravel; moved back } 1 \mathrm{ft} \text { and broke } \\
\text { through to sticky wood at } 11.1 \mathrm{ft}\end{array}$ & $3.1 \& 11.1$ \\
\hline 93 & sticky wood no gravel & 4 \\
\hline 94 & hard sticky wood & 9.2 \\
\hline 95 & hard sticky wood & 8.6 \\
\hline 96 & gravel over sticky wood at depth & 8.6 \\
\hline 97 & gravel at $3.6 \mathrm{ft}$; firm clay at depth & 13.1 \\
\hline 98 & all sediments no gravel & 13.5 \\
\hline 99 & very soft & 10.8 \\
\hline 100 & very soft & 10.8 \\
\hline 101 & very soft & 10.5 \\
\hline 102 & very soft & 10.4 \\
\hline 103 & very soft & 10.7 \\
\hline 104 & soft mud & 10.7 \\
\hline 105 & soft mud & 11 \\
\hline 106 & firm mud & 7.7 \\
\hline 107 & mud firm at bottom & 8.9 \\
\hline 108 & mud firmer at bottom & 9.1 \\
\hline 109 & gravel at $3.4 \mathrm{ft}$; wood at depth & 10.9 \\
\hline 110 & sticky wood & 5.1 \\
\hline 111 & wood & 9.1 \\
\hline 112 & wood & 8.9 \\
\hline 113 & wood & 9.4 \\
\hline 114 & gravel over wood at depth & 4.7 \\
\hline
\end{tabular}




\begin{tabular}{|c|c|c|}
\hline $\begin{array}{l}\text { Probe } \\
\text { ID }\end{array}$ & Notes (depths are ft below river bottom) & $\begin{array}{l}\text { Est. River Bottom } \\
\text { Penetration ( } \mathrm{ft} \text { ) }\end{array}$ \\
\hline 115 & mud & 13.2 \\
\hline 116 & mud & 13.3 \\
\hline 117 & wood & 7.9 \\
\hline 118 & sticky wood & 8.2 \\
\hline 119 & firm mud over wood at depth & 9.1 \\
\hline 120 & wood & 10.3 \\
\hline 121 & wood & 9.4 \\
\hline 122 & mud; gravel lens at $2.7-4.7 \mathrm{ft}$ & 12.7 \\
\hline 123 & $\begin{array}{l}\text { probe bumped against wood exposed above } \\
\text { river bottom }\end{array}$ & 9.6 \\
\hline 124 & firm, clay-like; could not penetrate & 3.7 \\
\hline 125 & mud & 12.6 \\
\hline 126 & sticky wood & 4.8 \\
\hline 127 & sticky wood & 10.8 \\
\hline 128 & firm, clay-like at $2.5 \mathrm{ft}$; soft wood at depth & 10.5 \\
\hline 129 & wood & 10.4 \\
\hline 130 & wood & 9.8 \\
\hline 131 & mud & 10.5 \\
\hline 132 & wood & 9.3 \\
\hline 133 & sticky wood & 8.1 \\
\hline 134 & mud & 10.7 \\
\hline 135 & mud & 10.4 \\
\hline 136 & mud & 12.5 \\
\hline 137 & sticky wood & 9.5 \\
\hline 138 & thin gravel on wood & 4.5 \\
\hline 139 & mud & 12.5 \\
\hline 140 & mud & 12.4 \\
\hline 141 & wood & 11.5 \\
\hline 142 & mud & 13.2 \\
\hline 143 & gravel & 7 \\
\hline 144 & mud & 12.6 \\
\hline 145 & mud & 12.6 \\
\hline 146 & mud & 12.3 \\
\hline 147 & mud; gravel lens & 10.6 \\
\hline 148 & mud & 10.5 \\
\hline 149 & mud & 10.5 \\
\hline 150 & narrow wood at $3.4 \mathrm{ft}$; mud to depth & 10.4 \\
\hline 151 & mud & 10.6 \\
\hline 152 & mud & 10.4 \\
\hline
\end{tabular}




\begin{tabular}{|c|c|c|}
\hline $\begin{array}{l}\text { Probe } \\
\text { ID }\end{array}$ & Notes (depths are ft below river bottom) & $\begin{array}{l}\text { Est. River Bottom } \\
\text { Penetration (ft) }\end{array}$ \\
\hline 153 & mud & 10.4 \\
\hline 154 & sticky wood & 3.2 \\
\hline 155 & mud & 11.4 \\
\hline 156 & mud & 11.2 \\
\hline 157 & mud & 10.9 \\
\hline 158 & mud & 8.4 \\
\hline 159 & mud & 9.6 \\
\hline 160 & gravel lens at $1.6 \mathrm{ft}$; mud to depth & 9.6 \\
\hline 161 & mud & 10.7 \\
\hline 162 & mud & 11 \\
\hline 163 & mud & 11.6 \\
\hline 164 & mud & 11.4 \\
\hline 165 & mud & 11.8 \\
\hline 166 & mud & 12 \\
\hline 167 & mud & 12.8 \\
\hline 168 & mud & 12.1 \\
\hline 169 & mud & 11.7 \\
\hline 170 & mud & 12 \\
\hline 171 & mud & 11.7 \\
\hline 172 & mud & 11.4 \\
\hline 173 & mud & 11.2 \\
\hline 174 & mud & 10.9 \\
\hline 175 & mud & 10.9 \\
\hline 176 & mud & 10.8 \\
\hline 177 & mud & 12.5 \\
\hline 178 & mud & 12.2 \\
\hline 179 & mud & 13.9 \\
\hline 180 & mud & 14.2 \\
\hline 181 & mud & 14.3 \\
\hline 182 & mud & 14.2 \\
\hline 183 & mud & 13.4 \\
\hline 184 & mud & 12.9 \\
\hline 185 & mud & 12.6 \\
\hline 186 & mud & 12.6 \\
\hline 187 & mud & 11.2 \\
\hline 188 & mud & 12.6 \\
\hline 189 & gravel lens; sticky wood at depth & 7.2 \\
\hline 190 & mud & 11.7 \\
\hline 191 & mud & 11.7 \\
\hline
\end{tabular}




\begin{tabular}{|c|c|c|}
\hline $\begin{array}{l}\text { Probe } \\
\text { ID }\end{array}$ & Notes (depths are ft below river bottom) & $\begin{array}{l}\text { Est. River Bottom } \\
\text { Penetration ( } \mathrm{ft} \text { ) }\end{array}$ \\
\hline 192 & mud & 11.7 \\
\hline 193 & mud & 12.3 \\
\hline 194 & mud & 13.2 \\
\hline 195 & mud & 13.9 \\
\hline 196 & mud & 14.2 \\
\hline 197 & sticky wood & 3.7 \\
\hline 198 & sticky wood & 5.3 \\
\hline 199 & wood & 6.6 \\
\hline 200 & wood & 7.5 \\
\hline 201 & gravelly at $6 \mathrm{ft}$, wood at depth & 7 \\
\hline 202 & gravelly over wood & 3.5 \\
\hline 203 & wood & 7.8 \\
\hline 204 & mud & 10.3 \\
\hline 205 & mud & 11 \\
\hline 206 & mud & 11.4 \\
\hline 207 & mud & 11.2 \\
\hline 208 & mud & 14.2 \\
\hline 209 & mud & 12 \\
\hline 210 & mud & 12.2 \\
\hline 211 & $\begin{array}{l}\text { firm sediment at depth; probe sticks in refusal } \\
\text { layer like clay }\end{array}$ & 16.0 \\
\hline 212 & firm sediment & 16.3 \\
\hline 213 & firm sediment; first PVC probe & 16.1 \\
\hline 214 & firm sediment & 16.0 \\
\hline 215 & firm sediment & 16.7 \\
\hline 216 & firm sediment & 16.6 \\
\hline 217 & firm sediment & 16.5 \\
\hline 218 & solid object & 7.5 \\
\hline 219 & firm sediment & 15.5 \\
\hline 220 & firm sediment & 16.5 \\
\hline 221 & firm sediment & 16.4 \\
\hline 222 & firm sediment & 15.3 \\
\hline 223 & pipe broke before completion & - \\
\hline 224 & firm sediment & 17.2 \\
\hline 225 & firm sediment & 16.2 \\
\hline 226 & solid object & 8.2 \\
\hline 227 & firm sediment & 15.1 \\
\hline 228 & firm sediment w/ gravel or shell & 17.8 \\
\hline 229 & firm sediment & 16.6 \\
\hline 230 & firm sediment & 15.9 \\
\hline
\end{tabular}




\begin{tabular}{|c|l|c|}
$\begin{array}{c}\text { Probe } \\
\text { ID }\end{array}$ & \multicolumn{1}{|c|}{ Notes (depths are ft below river bottom) } & $\begin{array}{c}\text { Est. River Bottom } \\
\text { Penetration (ft) }\end{array}$ \\
\hline $\mathbf{2 3 1}$ & firm sediment & 16.1 \\
\hline $\mathbf{2 3 2}$ & firm sediment & 15.2 \\
\hline $\mathbf{2 3 3}$ & firm sediment & 16.9 \\
\hline $\mathbf{2 3 4}$ & firm sediment & 17.1 \\
\hline $\mathbf{2 3 5}$ & firm sediment & 16.8 \\
\hline $\mathbf{2 3 6}$ & firm sediment w/ gravel or shell & 17.4 \\
\hline $\mathbf{2 3 7}$ & firm sediment w/ gravel or shell & 17.0 \\
\hline $\mathbf{2 3 8}$ & firm sediment & 17.6 \\
\hline $\mathbf{2 3 9}$ & firm sediment $w /$ gravel or shell & 17.8 \\
\hline
\end{tabular}


Appendix E: Texas Antiquities Permit 8926 and Agency Correspondence 


\section{TEXAS HISTORICAL COMMISSION \\ real places telling real stories}

Wednesday, May 29, 2019

Robert Gearhart

BOB Hydrographics, LLC

1315 Fall Creek Loop

Cedar Park, TX 78613-5820

Re: $\quad$ Project review under the Antiquities Code of Texas

Final Report: Orange County South Terminal Project

Texas Antiquities Permit \# 8926

Dear Colleague:

Thank you for your Antiquities Permit Application for the above referenced project. This letter presents the final copy of the permit from the Executive Director of the Texas Historical Commission (THC), the state agency responsible for administering the Antiquities Code of Texas.

Please keep this copy for your records. The Antiquities Permit investigations requires the production and submittal of one printed copy of the final report, a completed abstract form submitted via our online system, two copies of the tagged PDF final report on CD (one with site location information \& one without), and verification that any artifacts recovered and records produced during the investigations are curated at the repository listed in the permit. The abstract form maybe submitted via the THC website (www.thc.state.tx.us) or use url:

http://xapps.thc.state.tx.us/Abstract/login.aspx

Additionally, you must send the THC shapefiles showing the boundaries of the project area and the areas actually surveyed via email to archeological_projects@thc.texas.gov.

If you have any questions concerning this permit or if we can be of further assistance, please contact the reviewer, Amy Borgens at (512) 463-9505.

Sincerely,

Nick Barrett:

Antiquities Permit Coordinator

(512) 463-1858

Enclosures

Cc :Port of Beaumont

\section{E-2 | Page}




\section{State of Texas \\ TEXAS ANTIQUITIES COMMITTEE}

ARCHEOLOGY PERMIT 8926

This permit is issued by the Texas Historical Commission, hereafter referred to as the Commission, represented herein by and through its duly authorized and empowered representatives. The

Commission, under authority of the Texas Natural Resources Code, Title 9, Chapter 191, and subject to the conditions hereinafter set forth, grants this permit for:

\section{Underwater Survey}

To be performed on a potential or designated landmark or other public land known as:

Title: $\quad$ Orange County South Terminal Project

County: Orange

Location: Oxbow channel on north side of Neches River, 0.5 miles south of Rose City TX

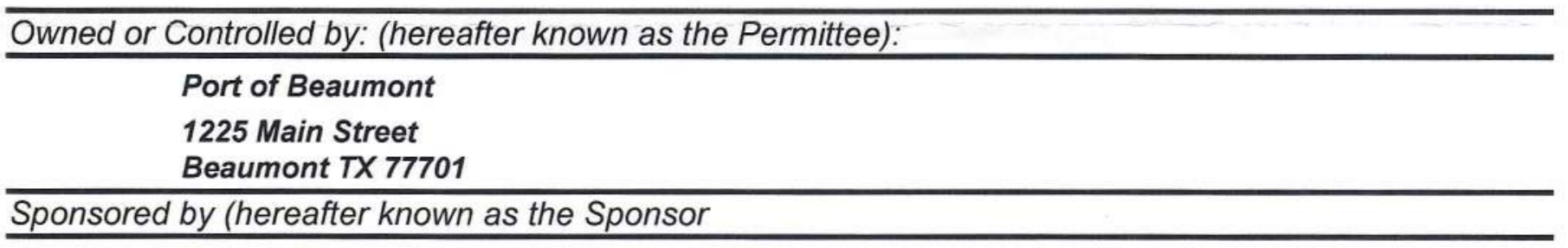

Port of Beaumont

1225 Main Street

Beaumont TX 77701

The Principal Investigator/Investigation Firm representing the Owner or Sponsor is:

\section{Robert Gearhart}

BOB Hydrographics, LLC

1315 Fall Creek Loop

Cedar Park, TX 78613-5820

This permit is to be in effect for a period of:

1 Years and 0 Months

and Will Expire on:

05/22/2020

During the preservation, analysis, and preparation of a final report or until further notice by the Commission, artifacts, field notes, and other data gathered during the investigation will be kept temporarily at:

BOB Hydrographics, LLC

Upon completion of the final permit report, the same artifacts, field notes, and other data will be placed in a permanent curatorial repository at:

\section{Center for Archaeological Research}

Scope of Work under this permit shall consist of:

Underwater survey, see attached scope for detail.

E-3 | Page 


\section{This permit is granted on the following terms and conditions:}

1) This project must be carried out in such a manner that the maximum amount of historic, scientific, archeological, and educational information will be recovered and preserved and must include the scientific, techniques for recovery, recording, preservation and analysis commonly used in archeological investigations. All survey level investigations must follow the state survey standards and the THC survey requirements established with the projects sponsor(s).

2) The Principal Investigator/Investigation Firm, serving for the Owner/Permittee and/or the Project Sponsor, is responsible for insuring that specimens, samples, artifacts, materials and records that are collected as a result of this permit are appropriately cleaned, and cataloged for curation. These tasks will be accomplished at no charge to the Commission, and all specimens, artifacts, materials, samples, and original field notes, maps, drawings, and photographs resulting from the investigations remain the property of the State of Texas, or its political subdivision, and must be curated at a certified repository. Verification of curation by the repository is also required, and duplicate copies of any requested records shall be furnished to the Commission before any permit will be considered complete.

3) The Principal Investigator/Investigation Firm serving for the Owner/Permittee, and/or the Project Sponsor is responsible for the publication of results of the investigations in a thorough technical report containing relevant descriptions, maps, documents, drawings, and photographs. A draft copy of the report must be submitted to the Commission for review and approval. Any changes to the draft report requested by the Commission must be made or addressed in the report, or under separate written response to the Commission. Once a draft has been approved by the Commission, one (1) printed, unbound copy of the final report containing at least one map with the plotted location of any and all sites recorded and two copies of the report in tagged PDF format on an archival quality CD or DVD shall be furnished to the commission. One copy must include the plotted location of any and all sites recorded and the other should not include the site location data. A paper copy and an electronic copy of the completed Abstracts in Texas Contract Archeology Summary Form must also be submitted with the final report to the Commission. (Printed copies of forms are available from the Commission or also online at www.thc. state.tx.us.)

4) If the Owner/Permittee, Project Sponsor or Principal Investigator/Investigation Firm fails to comply with any of the Commission's Rules of Practice and Procedure or with any of the specific terms of this permit, or fails to properly conduct or complete this project within the allotted time, the permit will fall into default status. A notification of Default status shall be sent to the Principal Investigator/Investigation Firm, and the Principal Investigator will not be eligible to be issued any new permits until such time that the conditions of this permit are complete or, if applicable, extended.

5) The Owner/Permittee, Project Sponsor, and Principal Investigator/Investigation Firm, in the conduct of the activities hereby authorizes, must comply with all laws, ordinances and regulations of the State of Texas and of its political subdivisions including, but not limited to, the Antiquities Code of Texas; they must conduct the investigation in such a manner as to afford protection to the rights of any and all lessees or easement holders or other persons having an interest in the property and they must return the property to its original condition insofar as possible, to leave it in a state which will not create hazard to life nor contribute to the deterioration of the site or adjacent lands by natural forces.

6) Any duly authorized and empowered representative of the Commission may, at any time, visit the site to inspect the fieldwork as well as the field records, materials, and specimens being recovered.

7) For reasons of site security associated with historical resources, the Project Sponsor (if not the Owner/Permittee), Principal Investigator, Owner, and Investigation Firm shall not issue any press releases, or divulge to the news media, either directly or indirectly, information regarding the specific location of, or other information that might endanger those resources, or their associated artifacts without first consulting with the Commission, and the State agency or political subdivision of the State that owns or controls the land where the resource has been discovered.

8) This permit may not be assigned by the Principal Investigator/Investigation Firm, Owner/Permittee, or Project Sponsor in whole, or in part to any other individual, organization, or corporation not specifically mentioned in this permit without the written consent of the Commission. 9) Hold Harmless: The Owner/Permittee hereby expressly releases the State and agrees that Owner/Permittee will hold harmless, indemnify, and defend (including reasonable attorney's fees and cost of litigation) the State, its officers, agents, and employees in their official and/or individual capacities from every liability, loss, or claim for damages to persons or property, direct or indirect of whatsoever nature arising out of, or in any way connected with, any of the activities covered under this permit.The provisions of this paragraph are solely for the benefit of the State and the Texas Historical Commission and are not intended to create or grant any rights, contractual or otherwise, to any other person or entity.

10) Addendum: The Owner/Permittee, Project Sponsor and Principal Investigator/Investigation Firm must abide by any addenda hereto attached.

Upon a finding that it is in the best interest of the State, this permit is issued on 05/22/2019.
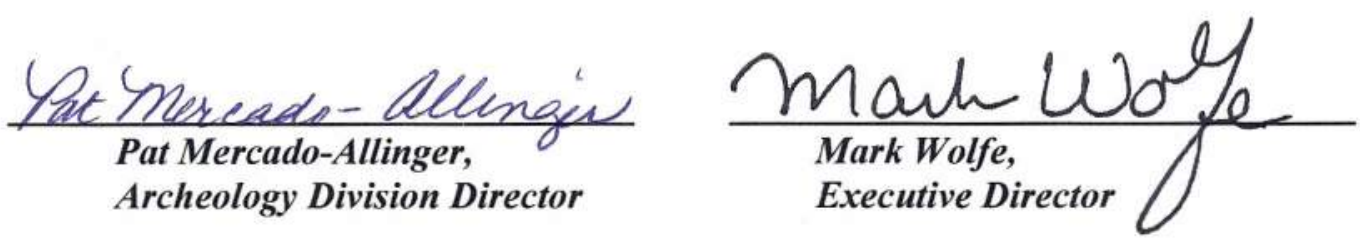

E-4 | Page 


\section{RE: Permit 8926, Orange County South Terminal Project; requesting amendment} 1 message

Amy Borgens <Amy.Borgens@thc.texas.gov>

Thu, Aug 22, 2019 at 6:39 PM

To: Robert Gearhart <bob.hydrographics@gmail.com>

Cc: Jesse Owens <jesse_owens@horizon-esi.com>, Nick Barrett <Nick.Barrett@thc.texas.gov>

Hello Bob,

Thank you for submitting a scope of work summarizing the additional work proposed for Anomalies 1-3. The permit file will be updated to include the additional investigation.

Regards,

Amy

Amy A. Borgens, MA

State Marine Archeologist

Archeology Division

Texas Historical Commission

P.O. Box 12276

Austin, Texas 78711

(office) 512.463.9505

(fax) 512.463.8927

www.thc.state.tx 
Cc: Jesse Owens <jesse_owens@horizon-esi.com>

Subject: Permit 8926, Orange County South Terminal Project; requesting amendment

CAUTION: External Email - This email originated from outside the THC email system. Do not click links or open attachments unless you recognize the sender and know the content is safe.

Amy,

My client for the above project, Horizon Environmental Services, Inc., has requested that I conduct further investigation of 3 magnetic anomalies before submitting a draft report for review. Fieldwork is planned for next week. The proposed effort is described in the attached pdf document. Two anomalies (1 and 3) are in a shallow area that was surveyed at closeorder. They can be probed from a boat. I plan to probe both anomalies to a depth of at least 6 feet, but not exceeding 10 feet below the river bottom, or to a depth of refusal. One anomaly (2) is located in a deep area that was not surveyed at close-order. Anomaly 2 is too deep for probing from a boat. The results of close-order magnetometer survey will determine whether Anomaly 2 is recommended for probing by divers. No diving is proposed at this time. I would appreciate your consideration of this request to amend Permit 8926 at your earliest convenience.

All my best,

\section{Bob Gearhart}

$512-517-8564$

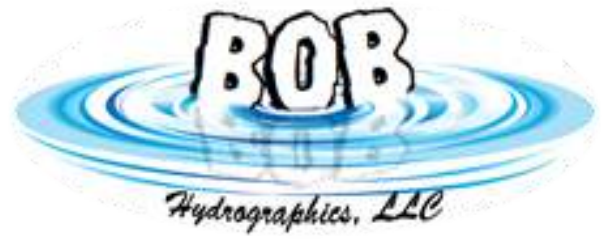

Permit 8926 amended scope.pdf $807 \mathrm{~K}$

\section{E-6 | Page}




\title{
Project Review: 202010303
}

\author{
1 message
}

noreply@thc.state.tx.us <noreply@thc.state.tx.us>

To: bob.hydrographics@gmail.com, reviews@thc.state.tx.us

Tue, Apr 7, 2020 at 5:20 PM

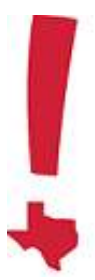

\author{
TEXAS HISTORICAL COMMISSION \\ real places telling real stories
}

Re: Project Review under Section 106 of the National Historic Preservation Act and/or the Antiquities Code of Texas Permit 8926

THC Tracking \#202010303

Orange County South Terminal Project

\section{Dear Client:}

Thank you for your submittal regarding the above-referenced project. This response represents the comments of the State Historic Preservation Officer, the Executive Director of the Texas Historical Commission (THC), pursuant to review under Section 106 of the National Historic Preservation Act and the Antiquities Code of Texas.

The review staff led by Amy Borgens has completed its review and has made the following determinations based on the information submitted for review:

\section{Archeology Comments}

- THC/SHPO concurs with information provided for the underwater project area.

- THC/SHPO has comments on the draft report submitted to this office for review.

- Draft report acceptable. Please submit another copy as a final report along with shapefiles showing the area where the archeological work was conducted. Shapefiles should be submitted electronically to Archeological_projects@thc.texas.gov.

- Underwater archeological sites, historic shipwrecks, and/or significant remote-sensing targets should be avoided and protected from construction impacts.

We have the following comments: For inclusion in the final report, please add an appendix to the document that contains the site form for $410 R 113$.

We look forward to further consultation with your office and hope to maintain a partnership that will foster effective historic preservation. Thank you for your cooperation in this review process, and for your efforts to preserve the irreplaceable heritage of Texas. If you have any questions concerning our review or if we can be of further assistance, please email the following reviewers: amy.borgens@thc.texas.gov

This response has been sent through the electronic THC review and compliance system (eTRAC). Submitting your project via eTRAC eliminates mailing delays and allows you to check the status of the review, receive an electronic response, and generate reports on your submissions. For more information, visit http://thc.texas.gov/etrac-system.

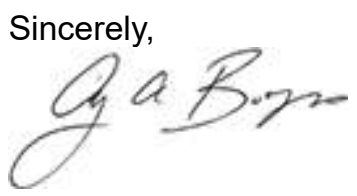

For Mark Wolfe, State Historic Preservation Officer

Executive Director, Texas Historical Commission

\section{E-7| Page}


Appendix F: 410R113 Site Form (Not for Public Disclosure)

F-1 | P a g e 